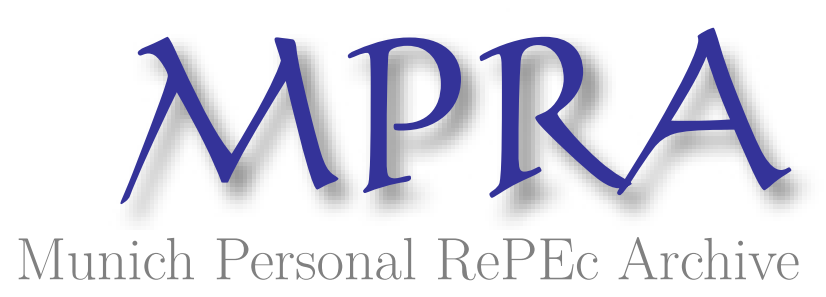

\title{
Effects of the 2001 Extension of Paid Parental Leave Provisions on Birth Seasonality in Canada
}

Compton, Janice and Tedds, Lindsay

Department of Economics, University of Manitoba, School of Public Administration, University of Victoria

25 August 2015

Online at https://mpra.ub.uni-muenchen.de/66280/

MPRA Paper No. 66280, posted 28 Aug 2015 05:04 UTC 
Effects of the 2001 Extension of Paid Parental Leave Provisions

on Birth Seasonality in Canada

Janice Compton and Lindsay M. Tedds*

August 24, 2015

\begin{abstract}
It is well known that there exists a strong seasonal pattern in births and that the pattern differs across geographic regions. While historically this seasonal pattern has been linked to exogenous factors, modern birth seasonality patterns can also be explained by purposive choice. If birth month of a child is at least partially chosen by the parents then, by extension, it can also be expected that this can be influenced by anything that changes the costs and benefits associated with that choice, including public policy. This paper explores the effect that the 2001 extension of paid parental leave benefits had on birth seasonality in Canada. Overall we find strong results that the pattern of birth seasonality in Canada changed after 2001, with a notable fall in spring births and an increase in late summer and early fall births. We discuss the potential effects of this unintended consequence, including those related to health and development, educational preparedness and outcomes, and econometric modelling.
\end{abstract}

Keywords: birth seasonality, policy determinants, parental leave, Canada

JEL Codes: J13, J38, H30

*Contact information: J. Compton, Department of Economics University of Manitoba, 15 Chancellors Circle Winnipeg, MB, R3T 5V5, Canada. E-mail: comptonj@cc.umanitoba.ca. L. Tedds, School of Public Administration, University of Victoria, PO Box 1700 STN CSC, Victoria, BC, V8W 2Y2, Canada. Email: Itedds@uvic.ca. 


\section{Introduction}

It is well known that there exists a strong seasonal pattern in births and that the pattern differs across geographic regions. ${ }^{1}$ This display of birth seasonality has been linked to such exogenous factors as the photoperiod, climate, holidays, nutrition, urbanization, and other sociocultural and environmental factors. ${ }^{2}$ More recently, researchers have been documenting changes in the historical seasonal patterns within countries since the advent of contraception, suggesting that modern birth seasonality patterns can also be explained by purposive choice (e.g. Van de Kaa 1987, Werschler \& Halli 1992, Bobak \& Gjonca 2001, Cassels 2002, Haandrikman \& Van Wissen 2008). If birth month of a child is at least partially purposefully chosen by the parents then, by extension, it can also be expected that this can be influenced by anything that changes the costs and benefits associated with that choice, including public policy.

There is some evidence to suggest that the timing of births can be influenced by public policy. Several studies have examined whether the delivery date of children, either delayed or expedited, is influenced by that tax treatment of children. The seminal work by Dickert-Conlin and Chandra (1999) considered the U.S. child tax benefit system that granted a whole year of tax relief to an individual or family that had a child in that tax year, even if the child was born on December 31. The authors found that such a system provided incentives for more children to be born in the last week of December rather than the first week of January; namely that a $\$ 50$ increase in benefits led to a 1.4 percentage point increase in the probability of a December birth. Using a more comprehensive data source, LaLumia, Sallee, and Turner (2015), however, found a smaller magnitude: that a $\$ 1000$ increase in benefits was necessary to incite the same

\footnotetext{
${ }^{1}$ For example, later summer and early fall peaks have been documented in the United States (Siever 1985) and southern Europe (Lam \& Miron 1994, and De beer 1997), Spring peaks in northern Europe (Lam \& Miron 1994, and De beer 1997) and Canada (Trovato \& Odynak 1993), and January peaks in the Soviet Union (Anderson and Silver 1988).

${ }^{2}$ See, for example, Trovato \& Odynak (1993) for a detailed discussion of these factors.
} 
behavourial response as reported by Dickert-Conlin and Chandra (1999). Kureishi and Wakabayahsi (2008) similarly found the Japanese tax deduction for dependent children, which, similar to the U.S. system grants a year's worth of tax relief to parents regardless of when in the tax year a child was born, increased the probability of a December birth.

Behavioural responses have also been found related to the parental benefit system and the school start date system. Gans and Leigh (2009) studied the effect of a $\$ 3,000$ Australian baby bonus that applied to children born on or after July 1, 2004. The authors found a significant increase in the number of births that occurred on July 1, 2004. Neugart and Ohlsson (2013) found that an increase in parental benefits that took effect on January 1, 2007 in Germany caused births to be shifted from December 2006 to January 2007. Finally, Dickert-Conlin and Elder (2010) examine whether school eligibility cutoff dates shift births to just prior to the legislated cut-off date, arguably as a way to reduce child care costs. They found no evidence that this occurs, a finding which is unsurprising given the offsetting desire to push a birth to just after the legislated cut-off date as a way to ensure the child has a physical, mental, and maturity advantage over their child's classmates.

All of these studies, however, focus on policy changes that affect delivery dates within a small window rather than birth seasonality per se. Whether there is the potential for policy to affect the timing of conception and, hence, birth seasonality is an interesting one, with many associated unintended consequences. It is this issue, the relationship between public policy and overall birth seasonality that is the focus of this paper. Policy influences on birth seasonality raise three issues for economists and public policy makers. First, there have been numerous studies documenting the health and economic outcomes that are influenced by one's month of birth. The effects of birth timing are most prominent in developing nations, where access to clean 
water and nutrition is seasonal and the absence of functional credit markets may prevent consumption smoothing, but effects are also found in developed countries. For example, there are a number of studies linking season (or month) of birth to a variety of health outcomes, such as schizophrenia (Dalen 1968), longevity (Huntington 1938), sudden infant death syndrome (Leiss \& Suchindran 1993), type I diabetes (Samuelsson, Johansson, \& Ludvigsson 1999), multiple sclerosis (Templar et al 2008), and epilepsy (Procopio, Marriott, \& Williams 1997). Correlations have been found between season of birth and intelligence, height, weight, and selfreported health (Kihlbom \& Johansson 2004) as well as between and elementary school test scores and the number of years of secondary school attendance (Puhani \& Weber, 2008). If public policy can be shown to significantly influence birth seasonality patterns, this may lead to changes in the distribution of health and development outcomes.

Second, there is an increasing focus on expanding early education, including universal day care, full day kindergarten, and the addition of junior kindergarten to the public school system on the assumption that these policies increase school preparedness and long term success. However, a child's ability to be 'prepared' for early education is directly related to their age and even just a few months age difference in these early years translates into significant skills differences. If birth seasonality is changing such that more children are younger upon entering the education system, the average `school readiness` level will be lower upon entry. This may result in the curriculum being too advanced for these children. In addition, to the extent that lower readiness at entry carries through to future years, test scores at higher grade levels may fall as these children enter these grades and may lead to the erroneous conclusion that the expansion of the early education system itself is to blame. 
Third, since school-leaving laws require that individuals remain in school until they reach their $16^{\text {th }}$ birthday, month of birth is correlated with the probability that an individual will finish high school. This correlation is strong enough that month of birth is often used as an instrument in econometric studies of the returns to education (e.g., Leigh \& Ryan 2005). This use of birth month as an instrumental variable in econometric analyses is based on the assumption that birth month is exogenous to personal characteristics and family background. ${ }^{3}$ Buckles and Hungerman (2014) show that this exogeneity assumption is faulty because, at least in the US, month of birth of a child differs significantly for married and unmarried women, and by age category. Notably, children born in the winter months are more likely to be born to unmarried and teenaged mothers than those born in the spring and summer months. The authors show that these demographic patterns in seasonality account for a large portion of birth month differences in educational attainment and wages. The results of this study demonstrate the invalidity of birth seasonality as an instrumental variable. If policy can be shown to affect birth seasonality patterns, this argument against using birth month as an instrumental variable is further strengthened.

Building on the existing literature, we reconsider the role that the parental benefit system plays in birth timing by exploring the potential of an expansion in parental leave benefits to affect the timing of conception, rather than just the timing of delivery. In particular, we investigate the effects that the 2001 extension of paid parental leave benefits on birth seasonality in Canada. Overall we find strong results that the pattern of birth seasonality in Canada changed after the expansion of the paid parental leave benefits, with a notable decline in spring births and an increase in late summer and early fall births. We provide two pieces of evidence to suggest

\footnotetext{
${ }^{3}$ See Buckles and Hungerman (2014) for an extensive list of examples of studies that have used birth month as an instrumental variable.
} 
that the changing pattern is due to the E.I. extension: first, we show that birth seasonality in the northern U.S. does not change following 2001; and second, the changing pattern in Canada is not found for unmarried, teen, or older mothers in Canada, groups who are least likely to plan births.

The paper is organized as follows: in section 2 we detail the Canadian maternity leave policy, focusing on the 2001 changes. In section 3 we review the historical patterns of birth seasonality in Canada and show the change in pattern following 2001. A comparison with aggregate data from the northern U.S. confirms that the pattern shift occurred only in Canada. In section 4, we use the microdata files of the Canadian Vital Statistics Data to determine that the pattern shift occurred for those groups of women most likely to be affected by the policy. Moreover, using multinomial logit regressions, we show that the changing pattern of seasonality continues to hold when demographic controls are included in the regression. Section 5 concludes with a discussion of the results.

\section{Canadian Maternity Leave Employment Insurance Scheme}

Arguably one of the most important policies related to births is paid maternity and parental benefits. In Canada, since 1971 qualified new mothers have been entitled to 15 weeks of paid maternity leave through the federally operated employment insurance scheme (Marshall 2003, p. 5), a duration that has remained unchanged since the policy`s inception. The rate of benefit and the eligibility requirements though has changed considerably since 1971 . The rate of benefit is set at a percentage of weekly earnings up to a set maximum. The benefit rate was regularly dropped throughout the 1971-1994 period, settling at 55\% where it has stayed since 1994 (Pulkingham \& Van Der Gaag 2004, p.117). Initially, new mothers with at least 20 weeks of insurable work were eligible for maternity benefits (Marshall 2003, p. 5). This changed to 700 hours of insurable work in 1996 and effective December 31, 2000 the eligibility was dropped to 600 hours (Pulkingham \& Van Der Gaag 2004, p.117). 
Paid parental benefits were introduced in Canada in 1990 when 10 weeks in paid parental leave were added to the maternity leave benefits. Paid parental leave benefits have the same eligibility and rate of benefit as paid maternity leave, but are more flexible in that parental leave benefits can be used by either parent or split between them, provided that they meet the qualification requirements (Marshall 2003, para. 1). The federal government signaled it was going to extend the parental leave benefit in the October 12, 1999 Speech from the Throne (Canada 1999) and the expansion was officially announced in Budget 2000 (Department of Finance 2000, pp. 137-138) on February 20, 2000. At this time, paid parental leave was significantly expanded for parents with a child born on or after December 31, 2000, with the duration being more than tripled from 10 weeks to 35 weeks. That is, effective December 31, 2000 the maximum paid combination of paid maternity and parental leave available was increased from approximately 6 months to about one year.

The only differences to the above maternity and parental benefits occur in two situations. First, about 20\% (Marshall 2010, pp. 5-6) of eligible new mothers receive an employer paid income top-up to these federal benefits. These income top ups average $\$ 300$ a week and last an average of 19 weeks (Marshall 2010, p. 6). Second, on January 1, 2006 Quebec introduced its Quebec Parental Insurance Plan (QPIP), which replaced the federal employment insurance plan for workers in Quebec. The QPIP is very similar to the federal plan except that if offers a higher benefit rate (up to 75\%) and a five week non transferrable paternity leave benefit (Marshall, p. 5)

We have outlined above several expansions of the maternity and parental leave system in Canada, however, we do not posit that most of these changes had any effect on birth seasonality. Cassels (2002) provides some insight into what type of policy changes might affect birth seasonality. He explores birth seasonality in Sweden 1900-1999 and finds a dramatic shift in 
birth seasonality in the 1990s, documenting a shift from spring births to summer births. He posits that this shift was due to increased leisure time that was indirectly caused by the expansion of legislated vacation to five weeks in 1994 and the recommendations that at least four of these five weeks take place in the month of June, July, or August. Cassels (2002, p. 108) argues that the change in birth seasonality observed in Sweden following this vacation time change is due to parents optimizing their time off following the birth of a child by coinciding the birth with extended vacation leaves. To the extent that this is true, his findings suggest that only those expansions that change the length of leave taken are likely to affect birth seasonality. Baker and Milligan (2008) show that the 1971 and 1990 changes in maternity and parental leave only increased the proportion claiming paid leave, not the length of leave taken. We equally posit that the 2006 QPIP introduction is unlike to change birth seasonality in Quebec, because these benefits are only modestly different from the federal expansion that had already occurred on December 31, 2000; however following Baker and Milligan (2008), this expansion could intensify the seasonality effects of the parental leave extension for Quebec.

The federal benefit expansion that occurred effective December 31, 2000, however, represented a significant increase in the amount of paid time off new parents could take. Whether this could have had an effect on the timing of births in Canada potentially depends on how it affected the amount of leave taken. Marshall (2003, p. 6) shows that following the 2001 parental leave changes, the return to work time for new mothers increased from 5-6 months to between 912 months. Similarly, Baker and Milligan (2008) demonstrate that the average increase in the amount of time off work following a birth was 3.5 months (Baker \& Milligan 2008), a finding reinforced by Hanratty and Trzcinski (2009). This increase in the amount of time off work due to the extended paid parental leave may, therefore, influence the timing of births in Canada, 
assuming that a significant portion of parents, notably mothers, take up these benefits. As noted by Baker and Milligan (2008, p.874) and Marshall (2010, p. 5) most (80-85\%) mothers are employed before giving birth and most of these mothers receive E.I. maternity or parental leave benefits. ${ }^{4}$ This means that $70-75 \%$ of new mothers in Canada receive paid maternity and parental leave benefits, which represents a significant portion of new parents. Further, these authors document that both trends, employment before birth and eligibility for E.I. prior to birth, have been rising since the parental leave expansion.

\section{Patterns of Birth Seasonality in Canada}

\subsection{Historical Patterns}

The historical seasonality of births in Canada has been previously documented in a few studies. The seminal paper in this field is Cowgill (1966), which included Canada in a large international comparison of birth seasonality. Cowgill notes a spring (April-June) peak of births in Canada along with a small secondary peak in September. This is contrasted with the seasonality pattern in the United States, which displays a major peak in September. However, as Canada is but one on many countries included in her study, there is little detail provided in support of this observation, including the source for the birth data. Halli (1989), the first study to focus exclusively on Canada, uses data from the 1984 Canadian Fertility Survey (CFS) to support Cowgill's findings, documenting a spring peak in births in Canada. However, the CFS survey is based on a small sample of women, relying on self-reported information.

The Cowgill (1966) and Halli (1989) results are confirmed in two Canadian studies based on vital statistics data. Werschler and Halli (1992) use birth data from Canadian vital statistics for the period 1980-1989 (excluding the territories) and find further support for a spring peak in

\footnotetext{
${ }^{4}$ As further noted by Marshall (2010, p. 5) those who were employed but who did not receive benefits were most likely to be self-employed, did not have enough insurable hours, or elected not to apply.
} 
Canada. They also document that there is little regional variation in this seasonal pattern. In an effort to explain this pattern, they compare the seasonal patterns in Canada to that of the northern U.S. states, which share similar climate, temperature, photoperiod, cultural, and socioeconomic factors. The northern U.S. states show a strong peak in August and September and a trough in the spring months, leaving the authors to conclude that the shown seasonal differences cannot be the results of oft referred to exogenous factors, but are unable to proffer any viable explanations for the difference.

The most comprehensive study of Canadian birth seasonality was done by Trovato and Odynak (1993). They compiled data on births from vital statistics data for the years $1926^{5}-1989$. They once again show that since 1926, births in Canada have peaked in spring with a secondary rise in September, and that this pattern has remained stable over this extended period of time and is similar across all provinces. Much like Werschler and Halli (1992), they are unable to provide a convincing explanation for this pattern and why it differs from the pattern observed in the northern U.S. states.

\subsection{Current Patterns}

To determine if this previously observed pattern in Canadian birth seasonality, namely spring peaks in births, can be confirmed and whether this pattern extends beyond 1989, we obtain the total number of births by month for the period $1981-2011 .{ }^{6}$ We first examine the quarterly trend in observed births, shown in Table 1. In this table, we are able to confirm the previously documented spring (April-June) peak for the period 1981-2001, with minor variations.

\footnotetext{
51926 represents the first year that complete and continuous vital statistics data for all the provinces is available. ${ }^{6}$ Data for 1991-2011 were obtained from Statistics Canada, CANSIM table 102-4502. Data prior to 1991 were obtained from the Statistics Canada Vital Statistics publication, which for the 1989-1992 period was called Health Reports. Supplement. No. 14, Births.
} 
Interestingly, there is a notable decline in births in just the last two quarters in 2000, as shown by the bordered numbers in the table. As noted previously, the expansion of the paid parental benefits was announced in the 1999 Speech from the Throne, though no commitment was made as to the timing of the expansion. The date of this Speech was October 1999 and if we use the median gestation period of 40 weeks this accords with July 2000, the beginning of the noted decline in births in Canada. The actual commitment to this expansion was not made until the following Budget, which was announced in February 2000. Again, if we use the median gestation period of 40 weeks this accords with December 2000, the end of the noted temporary decline in births. December 2000 is also notable because the new expanded parental leave policy took effect on December 31, 2000. While this evidence is correlational, it does suggest that women did indeed respond to the pending parental leave changes by reducing conceptions as they awaited the details of the benefit expansion. What is also interesting is that we do not observe an immediate spike in births in January 2001 to offset this two quarter decrease. In fact, 2001 looks very much like the previous years, unsurprisingly suggesting it is much easier to cease conceptions than it is to recommence conceptions. We are not aware of any other study that documents a possible change in conceptions due to public policy announcements of this nature. Table 1 also shows a notable change in birth seasonality starting in 2002 . This is the first year where the peak birth season shifts noticeably from spring to the fall. In fact, this shift is noted in every year from 2002 until the end of the vital statistics births data series, suggesting a permanent change in birth seasonality in Canada that occurred after the parental leave expansion. This suggests that the changes in birth seasonality in response to policy may not immediately show up 40 weeks after the policy change. Instead, it takes some adjustment time. In the case of the parental leave expansion, there was a one year delay. 
Of course the data in Table 1 are unadjusted time series data and any observed changes could be, in whole or in part, due to trend, cyclical, and irregular components of the series, rather than in seasonality itself. To examine if the seasonal component of births changed, we need to extract the seasonal component. To do this, we first adjust the monthly data on births to equal length of month (Cassel 2002, p. 102) and then calculate ratio values using a centered-12-month moving mean as is standard in the literature. If there is no seasonal pattern then this adjustment gives a value of 100 for each month, and if there is a seasonal pattern then the resulting ratio values are interpreted as the percentage deviation from the mean monthly number of births in a year.

For the first step in visualizing the seasonal pattern we further set the ratio values such that May equals 100 in every year as an initial way to visually confirm the spring peak previously identified in the literature and in the raw data and to easily visualize any changes to that pattern over our time series. If we plot this series over time, we should see that the May normalized series peaks around May, though since the previous literature reported a spring peak and not necessarily a May peak, we expect some noise around these months. Further, if the seasonal pattern changes during the time period, particularly post-2000, it will be easy to see in the plotted series. Figure 1 displays the May normalized seasonal pattern of births for 1981-2011. The horizontal line is set at 100. If May is the peak seasonal month then the series will touch the line in that month and be lower in every other month. If the peak is not in May, the peak will appear above the 100 line. We also set a vertical line in January 2001 to mark the E.I. parental leave expansion. If the parental leave resulted in a shift in seasonality than the pattern to the right of this line will differ from the pattern to the left of this line. 
Figure 1 confirms the historically reported Canadian seasonal pattern of spring peaks in births throughout the 1980s and 1990s. In most years, the peak actually aligns with the month of May, with some years peaking alternatively in April or June. We also see that in 2001 the pattern of birth seasonality matches that for the 1990s, but starting in 2002 we begin to see a shift in the pattern of birth seasonality: namely, a shift from May being the peak birth month to September being the peak birth month, starting in 2002 and in every year after that.

[Figure 1 here]

It could be argued that the results could be driven by a change in birth seasonality in one of Canada's most populous provinces, namely Quebec. This is because Quebec has a rich history of social programs designed to support fertility, including universal day care, and that have been implemented during our sample period. As a result, it is worth considering if there are differences in this pattern in Quebec as compared to the rest of Canada. Figure 2 disaggregates the data for the province of Quebec and the rest of Canada. Figure 2 clearly shows that we see similar results for Quebec as we do the rest of Canada. Quebec does, however, show slightly more variability in the pre-2001 seasonality pattern, but a similar pattern post-2000 as that in the rest of Canada. As expected, following the introduction of the QPIP in 2006, we see an amplification of the changed seasonal pattern, but not an overall change in the post-2001 seasonal pattern.

[Figure 2 here] 
Similar to Werschler and Halli (1992), we compare the results in Figure 1 and 2 to comparable data from the northern U.S. States in an effort to isolate the change observed in Canada to the policy change as opposed to any shared exogenous shocks. Figure 3 shows the comparable data for the northern U.S. states. ${ }^{7}$ Figure 3 reinforces the fact that the northern U.S. states do have a different seasonal pattern to that in Canada. These states show a strong summer to early fall peak, and no change in that pattern is observed following 2000.

[Figure 3 here]

Of course, it is impossible to determine from Figures 1-3 if the observed seasonality change is statistically significant. To determine if the observed change in birth seasonality is statistically significant, we run the following OLS regression, without intercept terms, on both the pre-2001 period and the post 2000 period:

$$
N B_{m}=\sum_{c=1}^{12} \lambda_{c} \text { Month }+\varepsilon_{t}
$$

$N B_{m}$ represents the ratio values discussed above (though not normalized to May) where deviations from 100, represent seasonality. Month are monthly dummy variables. If there was a significant change in birth seasonality following the parental leave policy change then we would expect to see some of the monthly coefficients being statistically significantly different across

\footnotetext{
${ }^{7}$ U.S. vital statistics birth data back to 1968 are publicly available for free download from http://www.cdc.gov/nchs/data_access/Vitalstatsonline.htm. In the aggregate data on births, state level data is available to 2013, however, state information is censored in the individual level data starting in 2005. We included States above the $42^{\text {nd }}$ parallel: Idaho, Illinois, Iowa, Maine, Massachusetts, Michigan, Minnesota, Montana, Nebraska, New Hampshire, New York, North Dakota, Oregon, South Dakota, Washington, Wisconsin and Wyoming.
} 
the regression models. Given the pattern change observed in Figure 1, specifically we would expect to see lower coefficients on the spring months and higher coefficients on the fall months in the post-2000 regression for Canada, and for there to be no difference pre- and post- 2001 for the northern United States.

The results from this regression are presented in Figure $4 .{ }^{8}$ Figure 4 plots the regression coefficients for Canada and the United States both pre and post policy change. The vertical lines on the monthly points represent the $95 \%$ confidence interval. The top panel in Figure 4 presents the results for Canada and the bottom panel for the northern United States. The results in the top panel of Figure 4 clearly show a change in birth seasonality in Canada following the parental leave policy change in 2001. Prior to 2001, the peak birth month is May and is nearly 6\% above the mean. In addition, there is a clear secondary peak in April with births $4.6 \%$ above the mean and a tertiary peak June with births $4 \%$ above the mean. This reconfirms the previous literature documenting a Spring peak in births in Canada. Births decline every month following the May peak, except for September, when there is an uptick in births, though at $3.5 \%$ above the mean it is well below all the Spring months. Post-2001, the months of March, April, and May, all show statistically significant declines following the policy change. June also falls, but the change is not quite statistically significant. Post-2001 May is only $2.7 \%$ above the mean and April 1.2\% above the mean. In addition, March declines from $2.94 \%$ above the mean to just below the mean. In lieu, the months of August through to November all show statistically significant increases, with the peak birth month now occurring in September. Post-2001, births in September are nearly $6.5 \%$ above the mean, which is higher than the pre-2001 May peak. ${ }^{9}$ In total, the change means that spring (April-June) births dropped from $14.53 \%$ above the mean to $7 \%$ and late summer

\footnotetext{
${ }^{8}$ The regression results are provided in the appendix in Table A.1.

${ }^{9}$ We obtain similar results for both Quebec and the rest of Canada, excluding Quebec. See Table A.2
} 
early fall births (August-October) rose from $0.83 \%$ above the mean to over $10 \%$. These results reaffirm the trend shown in Table 1; that much fewer babies are now being born in the Spring and much more are being born in the late Summer and Fall.

[Figure 4 here]

The bottom panel of Figure 4 shows the same results for the Northern US. Not only does Figure 4 document a different seasonal pattern, where the northern U.S. states have a clear July peak, but for the northern US, there are no statistically significant changes in birth seasonality post-2000. This implies that the changes observed in Canada post-2000 were unique to that geographic region, giving credence to the supposition that the changes to the parental leave policy affected the timing of births in Canada.

The evidence from the aggregate birth data, however, is still weak. The change in birth seasonality patterns that are being observed, while convincing, could be due to changes in the seasonality patterns within demographic groups or due to changing demographics. Controlling for demographic information is important in this context as it is well known that the demographic profile of new mothers has changed over this period. Notably, not only are there are more women over the age of 30 having children, but more women over 30 giving birth are also having their first child and this could be giving rise to the changing seasonal pattern. The next section of this paper considers the results from administrative birth data which allows us to control for such demographic and other changes. 


\section{Vital Statistics Detail Files}

The Canadian Vital Statistics Birth detail files contain information on every reported live birth in Canada. The data is obtained from birth registrations in each reporting geographic region. For each live birth the following information is available in the data files: date and place of birth; child's sex, birth weight, and gestational age; parent's age, marital status, and birthplace; mother's place of residence; whether the birth was a single or multiple birth, and parity. ${ }^{10}$ We limit the data to all live births from 1981-2008 to mothers who were over the age of 12 at the time of the birth and were a resident of one of the ten provinces. ${ }^{11}$

As in previous sections, we compare the Canadian results to comparable data from the northern U.S. States in an effort to isolate the change observed in Canada to the parental leave extension as opposed to any shared exogenous shocks. The U.S. Vital Statistics Birth detail files contain information on every reported live birth in each reporting geographic region in the U.S. The data includes comparable demographic indicators for the mother's marital status ${ }^{12}$ and age, whether it is the mother's first birth, and whether the child is of low birth weight. We limit the data to all live births from $1981^{13}$ onwards to mothers who were over the age of 12 at the time of the birth and were a resident of one of the 17 northern U.S. states. Unfortunately, effective 2005, information on the mother's state of resident is no longer available in the detail files. As a result, we are forced to limit the U.S. data from 1981-2004. Because only three years are available for the northern U.S. states post the E.I. policy change, the analysis and strength of this data as a counterfactual is weakened.

\footnotetext{
${ }^{10}$ The Canadian Vital Statistics detail files are not publicly available. Instead access to this data was made available through the Research Data Centres. Through a pilot project, Statistics Canada granted access to the detail files for the years 1974 to 2008 inclusive.

${ }^{11}$ The Territories are excluded to limit variations due to climate within the sample.

${ }^{12}$ Unfortunately, the legal definition of marriage differs across the two jurisdictions and we are unable to create consistent categories with the data available.

${ }^{13} 1981$ is the first year that all northern U.S. states report $100 \%$ of their births in the Vital Statistics Birth detail files.
} 
With the aggregate data used in the previous section, we only know the actual birth month. Another advantage of using the detail files is that information on gestational age can be used to calculate expected birth month. If parents purposefully chose a birth month, it is typically done at the time of conception based on a 40 week gestational period. Of course, many expectant mothers will not meet or will even exceed this gestational period for a variety of reasons, leading to a difference between actual birth month and expected birth month at time of conception. To control for this variability, the work that follows is based on the expected month of birth.

\subsection{Aggregated Data}

We first ran regressions similar to those from equation 1, except the dependent variable in this case is based on the number of expected births per month rather than the number of actual number births per month. ${ }^{14}$ Figure 5 shows the coefficients and confidence intervals for the preand post-E.I. regressions. ${ }^{15}$ The results are similar to those observed in Figure 4. In Canada, prior to the E.I. expansion, the peak occurred in the spring though using expected month of birth the peak shifts to April, which is $7.1 \%$ above the mean. After the E.I. expansion, there is a clear increase in the proportion of expected births occurring in the late summer and fall months, with offsetting reductions in births occurring in the months of March-June. As with actual month of birth, the seasonal peak has now shifted to September, which is now $8.2 \%$ above the mean. In total, using expected birth month, the change means that spring (April-June) births dropped from $17.7 \%$ above the mean to $10.9 \%$ and late summer early fall births (August-October) rose from

\footnotetext{
${ }^{14}$ As in the previous section, these data are aggregated to monthly totals, adjusted for days in month and leap years, and the seasonal component obtained using a centred 12-month average.

${ }^{15}$ The regression results are provided in the appendix in Table A.3.
} 
$2.79 \%$ above the mean to $9.54 \%$. We again found no change in the seasonal pattern in the northern U.S. following $2001 .^{16}$

\section{[Figure 5 here]}

While the evidence continues to suggest that the change is the seasonal pattern in Canada is in response to the parental leave policy change, the available data does not let us test this hypothesis directly. We can, however, provide more indirect evidence in support of this hypothesis by considering the seasonal birth patterns of specific demographic groups. It is unreasonable to assume that the change in parental leave policy affected the timing of birth decisions for every woman. Those most likely to be affected by the policy change are those who claim the parental leave benefits and those most likely to be planning their births. Unfortunately, we do not have information related to qualification for parental leave benefits, but we do have information on marital status and age which are indicators, albeit noisy ones, of a planned birth. ${ }^{17} \mathrm{We}$ focus on the characteristics of mothers, rather than fathers, since fathers are much less likely to claim benefits and because the age of fathers is less relevant to the ability to plan conception than is the age of mothers ${ }^{18}$.

\footnotetext{
${ }^{16}$ As a robustness check, we ran the regression excluding the years 2000 and 2001, and find that the previously noted decline in conceptions following the policy announcement is not driving the results. Additionally, omitting Quebec from the analysis does not alter the resulting pattern. These results are available on request.

${ }^{17}$ Data from the U.S. show that the proportion of pregnancies that are unintended have been stable across the last two decades and range from $27 \%$ for married women to $74 \%$ for unmarried women. Pregnancies of teenaged women are most likely to be unintended (82\%), compared with $36 \%$ for women aged 25-39. There are also correlations between unintended pregnancies and education and race, but these are less pronounced (see Henshaw (1998), Finer \& Henshaw (2006), Finer \& Zolna (2011)).

${ }^{18}$ The proportion of fathers claiming parental leave did increase dramatically after the extension of the E.I. parental leave, rising from $3 \%$ in 2000 to $20 \%$ in 2006 . However, this increase is largely due to the higher claim rates in Quebec following the introduction of parental benefits that are reserved for fathers. The QPIP program includes 5 weeks of non-transferable paternity leave, effective January 2006. In 2006, the rate of new Quebec fathers receiving this benefit was 56\%, the take-up rate for fathers in the rest of Canada was 11\%. (Marshall 2008, p. 9).
} 
Figure 6 shows the regression coefficients from equation 1 for subsamples of the data. The first row shows the coefficients and confidence intervals for the subsamples of married and unmarried women; the second and third rows show the coefficients and standard errors for married women in specific age categories. The seasonal shift here is apparent for both married and unmarried mothers, although the fall in spring births is significant only for married mothers. The unclear result may be due to the changing legal definition of marriage across provinces and over time as well as lack of clarity on the birth registration form. We do clearly see that, among the group defined as married, there is a clear shift in the seasonal pattern only for those aged 2534 , the subset of women most likely to be planning a pregnancy. ${ }^{19}$

\subsection{Multinomial Logit Regressions on Seasonality Patterns}

With the aggregate data providing clear evidence of a shift in birth seasonality in Canada following the expansion of parental leave, it is worthwhile to use the individual birth level data to determine if the change in the seasonal pattern holds after controlling for demographic characteristics. In particular, since the definition of marriage differs across time and province, our finding that the seasonal pattern change is predominantly found for married mothers is sullied by the changing definition of marriage. Within year and province, however, whether or not a mother is legally married provides information as to the relative probability that the pregnancy is planned. Given our assumption that parents can choose the birth month of their child, we can model the probability of a birth occurring in each month using a multinomial logit model as follows:

\footnotetext{
${ }^{19}$ The results on the U.S. sample showed no significant seasonality change for any marital status or age group subsample (not shown).
} 


$$
\begin{aligned}
& \operatorname{Pr} o b(Y=j)=\frac{e^{\beta_{j}^{\prime} X_{i}}}{1+\sum_{k=1}^{11} e^{\beta_{k}^{\prime} X_{i}}} \quad \text { for } j=1,2, \ldots 11 \\
& \operatorname{Pr} o b(Y=0)=\frac{1}{1+\sum_{k=1}^{11} e^{\beta_{k}^{\prime} X_{i}}}
\end{aligned}
$$

where $X_{i}$ includes demographic, policy, time, and geographic variables. The demographic variables include indicators for the mother's marital status and age, whether it is the mother's first birth, and whether the child is of low birth weight. ${ }^{20}$ The policy variable is an indicator that takes a value of one in the year 2001 and onwards and represents the parental leave policy change. The time and geographic variables include a cubic time trend ${ }^{21}$ as well as controls for mother's province of residence.

The results from the multinomial logit model are show in Figures $7 \mathrm{a}-7 \mathrm{c}{ }^{22}$ These figures plot the relative risk ratios obtained from equation 2 where the reference group (the omitted category $j$ ) is May births. The standard interpretation of the relative risk ratios is for a unit change in the predictor variable, the relative risk ratio of a given outcome relative to the reference group is expected to change by a factor of the respective parameter estimate given the variables in the model are held constant. Because May is the omitted month, it is given a value of 1. A month that takes a value below 1 means that the relative risk of birth in that month is lower than May, a value above one means that the relative risk of birth in that month is higher than May. We only report the coefficients on the policy variable as these are the coefficients of

\footnotetext{
${ }^{20}$ This variable is equal to one when the child is less than 2500 grams at birth. Under the assumption that low birth weight is correlated with unintended pregnancies we include this indicator to better isolate planned seasonality patterns.

${ }^{21}$ Results are similar when a linear time trend is used.

${ }^{22}$ The associated regression results are reported in Tables A.4 and A.5.
} 
interest. Given the number of observations ${ }^{23}$ the statistical significance of the coefficients is of little consequence. Rather, we are interested in whether the seasonal pattern shift observed in the aggregated data remains after controlling for demographics and geography.

The first row in Figure 7a shows the results for Canada and the U.S. when only time trend indicators are included. A clear pattern shift is observed for Canada, with the previous May peak being replaced by a September peak for the years following 2000. In fact, all months after June following the E.I. change show an increase in their relative risk ratios compared to May. The results here are consistent with the aggregated results. Prior to the E.I. extension, the probability that a birth occurs from in September is $3 \%$ lower than the probability that a birth occurs in May. Following the E.I. extension, the probability of a September birth is $6.6 \%$ higher than the probability of a May birth. ${ }^{24}$.We again find no pattern change in the U.S. data.

\section{[Figure 7a here]}

The second row shows the relative risk ratios for the regression including all control variables. Interestingly, when controls are included in the regression, the base seasonal pattern in Canada shows a September peak both before and after the policy change. The seasonal pattern change — the increase in the probability that the birth occurs in the fall-remains. Controlling for demographic and geographic indicators, the probability of a September birth pre-E.I. extension is 7.7\% higher than the probability of a May birth. Following the E.I. extension, the probability of a September birth increases to $13 \%$ over the probability of a May birth Again there is no change in the U.S. seasonal pattern.

\footnotetext{
${ }^{23} 9,546,945$ in the Canadian data, and 25,192,755 in the U.S. data.

${ }^{24}$ See Table A.4. The relative risk ratio on the constant term represents the pre-E.I. regime. To obtain the post-E.I. relative risk ration, the constant and the Post-2000 indicator are multiplied together.
} 
To illustrate that the policy may have had stronger effects on certain demographic groups, the regression is augmented to include interaction terms between the policy variable and demographic variables. The resulting coefficients are presented as relative risk ratios in Figures $7 \mathrm{~b}$ and $7 \mathrm{c}{ }^{25}$ The graphs confirm that the pattern shift in Canada is due primarily to married mothers, and to mothers aged 25-34, as the pattern shift is observed only for these interactions. Although the legal definition of marriage changes through time and across provinces, once these factors are included as controls the indicator for married provides information about the stability of the relationship and the likelihood that the birth was planned.

[Figure $7 \mathrm{~b}$ and $7 \mathrm{c}$ here]

Overall, the results provide clear evidence that there was a change in the seasonal pattern of births in Canada following the parental leave policy change in 2001. This change in the seasonal pattern holds even when controlling for changes in demographic composition and exogenous factors. Although not a definitive test of causality, we provide two pieces of evidence to suggest that the policy may have induced the change in seasonality: (1) the seasonality change did not occur in the northern U.S. states and (2) seasonality patterns did not change significantly for those mothers least likely to respond to the parental leave policy change in birth planningunmarried mothers and mothers under the age of 25 or over the age of 35 .

\section{Discussion}

The main conclusion of this paper-that the parental leave extension of 2001 altered the seasonality pattern of births in Canada-has a number of implications. Notably, the results point

\footnotetext{
${ }^{25}$ Corresponding regression results are provided in Table A. 5.
} 
to an unexpected consequence of the parental leave policy extension-the change in birth seasonality—which may have several domino effects.

First, the change in birth seasonality itself may lead to various health and development differences that may be influenced by birth season. Foster and Roenneberg (2008) provide a summary of findings linking health outcomes and birth seasonality. The literature review suggests that the negative health effects of birth seasonality are concentrated on those born between March and June. Although children born in the spring (in the northern Hemisphere), have higher birthweights, on average, than those born later in the year (Currie \& Schwandt 2013), they are also more likely to develop childhood diabetes. (Foster \& Roenneberg 2008, p. R790) schizophrenia (Torrey et al, 1997, and Saha et al, 2006) ${ }^{26}$ and multiple sclerosis (Templer et al., 1992, and Willer et al., 2005). This may mean that there are positive health outcomes along these dimensions related to the shift from spring to late summer and early fall births.

Second, as the shift in the seasonal patterns following the parental leave extension has resulted in more births at the end of the calendar year, this may lead to changes in educational preparedness and educational outcomes. As many provinces are using calendar year entry for kindergarten, ${ }^{27}$ the change in birth seasonality results in younger students in kindergarten. If younger students are at a disadvantage academically, the changing distribution may have a negative effect on grade level achievement. Moreover, Bedard and Dhuey (2006) demonstrate that the negative effects of entering school at a relatively early age are long-lasting, as those entering school at a young age have lower test scores even in high school. To gauge the size of the effect-for the decade before $2001,51 \%$ of children were born in the first half of the calendar year, while $49 \%$ were born in the second half. These proportions have reversed

\footnotetext{
${ }^{26}$ This argument is based on Vitamin D exposure early in life. The use of Vitamin D supplements is now strongly encouraged for young children, so this finding may not be continued.

${ }^{27}$ Those with calendar year entry requirements are NF, NB, ON, MB, AB and BC.
} 
following the 2001 E.I. extension and a slim majority of children are now born in the latter half of the year. ${ }^{28}$ Although the effect is not large, small declines in early year test scores and school readiness may be expected.

However both of the above affects (medical and school readiness) may be offset by the observation that the changing seasonality pattern comes primarily from married women between the ages of 24-35. Prior to the parental leave extension, Canadian children born in Oct-Dec were significantly less likely to be born to a married woman compared to children born in January. ${ }^{29}$ Following the E.I. extension, children born late in the year are no less likely to be born to a married woman compared with those born in January. To the extent that marital status of mother may affect school readiness and early year test scores, as well as birthweight and cognitive abilities, the increasing proportion of children born in the latter months of the year may not reduce average achievement. Currie and Schwandt (2013), however, argue that the strength of seasonal effects on health are not diminished by mothers' demographic characteristics. Further research on child outcomes that allows for different seasonality patterns by demographic characteristics is needed to better isolate the effects of seasonality on health and achievement.

Finally, our results argue strongly against using month or season of birth as an instrumental variable. While a number of other papers have shown that seasonal patterns of birth are related to the marital status, age, and education of the mother, the relationship between the socio-economic status of mothers and seasonality are less clear. Buckles and Hungerman (2014) argue that the difference in the seasonal patterns by characteristics of the mother is due to the

\footnotetext{
${ }^{28}$ Calculated from the data in Table 1.

${ }^{29}$ We replicated regressions similar to those in Buckles and Hungerman (2014) for Canada. The results discussed are from probit regressions on the probability that a child is born to a married mother. Full regression results are available on request.
} 
different reaction of married and unmarried women to temperature fluctuations for sexual

frequency. We argue that the differences may also be the result of different reactions to policy. 
Table 1: Quarterly Observed Births, Canada, 1981-2011

\begin{tabular}{|c|c|c|c|c|c|}
\hline Year & Jan-March & Apr-June & July-Sept & Oct-Dec & Total \\
\hline 1981 & 89,860 & 95,599 & 95,745 & 89,132 & 370,336 \\
\hline 1982 & 90,867 & 96,136 & 96,022 & 89,857 & 372,882 \\
\hline 1983 & 90,272 & 97,346 & 95,476 & 90,598 & 373,692 \\
\hline 1984 & 91,429 & 97,033 & 98,012 & 90,577 & 377,051 \\
\hline 1985 & 90,085 & 97,600 & 97,169 & 90,173 & 375,027 \\
\hline 1986 & 89,478 & 97,805 & 96,224 & 88,924 & 372,431 \\
\hline 1987 & 89,267 & 98,172 & 94,143 & 87,859 & 369,441 \\
\hline 1988 & 90,036 & 97,481 & 97,753 & 90,473 & 375,743 \\
\hline 1989 & 92,978 & 101,901 & 101,782 & 95,264 & 391,925 \\
\hline 1990 & 98,369 & 106,868 & 104,427 & 95,005 & 404,669 \\
\hline 1991 & 97,191 & 105,861 & 103,809 & 95,672 & 402,533 \\
\hline 1992 & 98,480 & 105,146 & 101,832 & 93,185 & 398,643 \\
\hline 1993 & 94,801 & 102,363 & 99,855 & 91,375 & 388,394 \\
\hline 1994 & 93,553 & 101,376 & 99,235 & 90,950 & 385,114 \\
\hline 1995 & 92,452 & 99,361 & 98,615 & 87,588 & 378,016 \\
\hline 1996 & 90,013 & 96,237 & 94,640 & 85,310 & 366,200 \\
\hline 1997 & 84,968 & 92,395 & 89,500 & 81,735 & 348,598 \\
\hline 1998 & 83,424 & 90,464 & 88,881 & 79,649 & 342,418 \\
\hline 1999 & 81,890 & 87,875 & 87,772 & 79,712 & 337,249 \\
\hline 2000 & 82,627 & 86,801 & 83,173 & 75,281 & 327,882 \\
\hline 2001 & 81,350 & 87,303 & 86,123 & 78,968 & 333,744 \\
\hline 2002 & 79,345 & 83,719 & 86,618 & 79,120 & 328,802 \\
\hline 2003 & 79,299 & 85,486 & 88,856 & 81,561 & 335,202 \\
\hline 2004 & 81,583 & 85,762 & 87,992 & 81,735 & 337,072 \\
\hline 2005 & 81,190 & 88,353 & 90,369 & 82,264 & 342,176 \\
\hline 2006 & 83,594 & 89,855 & 94,248 & 86,920 & 354,617 \\
\hline 2007 & 86,410 & 93,338 & 97,435 & 90,681 & 367,864 \\
\hline 2008 & 90,170 & 95,409 & 100,441 & 91,866 & 377,886 \\
\hline 2009 & 90,410 & 96,573 & 101,200 & 92,680 & 380,863 \\
\hline 2010 & 90,371 & 95,122 & 98,763 & 92,957 & 377,213 \\
\hline 2011 & 89,553 & 95,678 & 100,674 & 91,731 & 377,636 \\
\hline
\end{tabular}

Source: Statistics Canada, CANSIM table 102-4502 


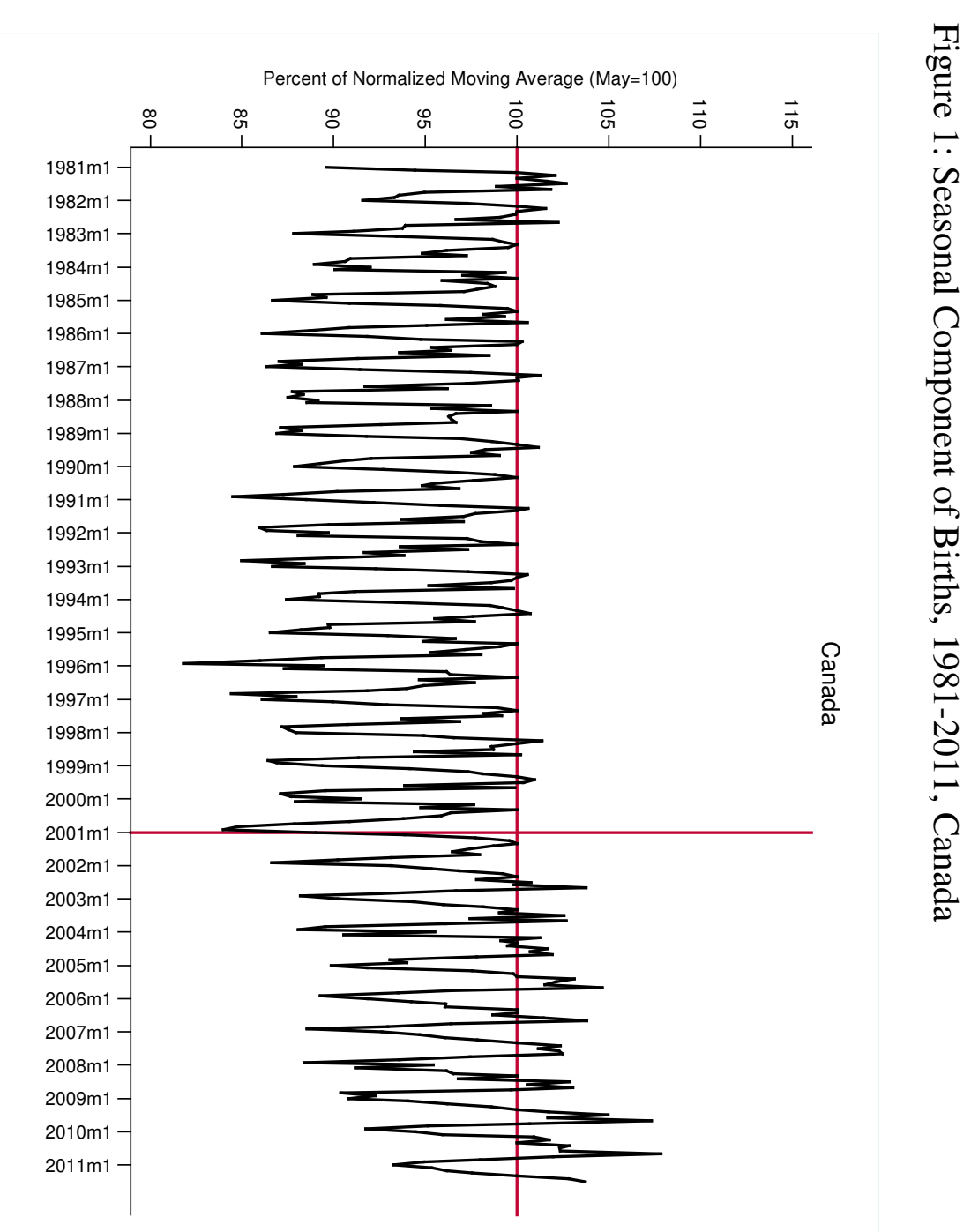



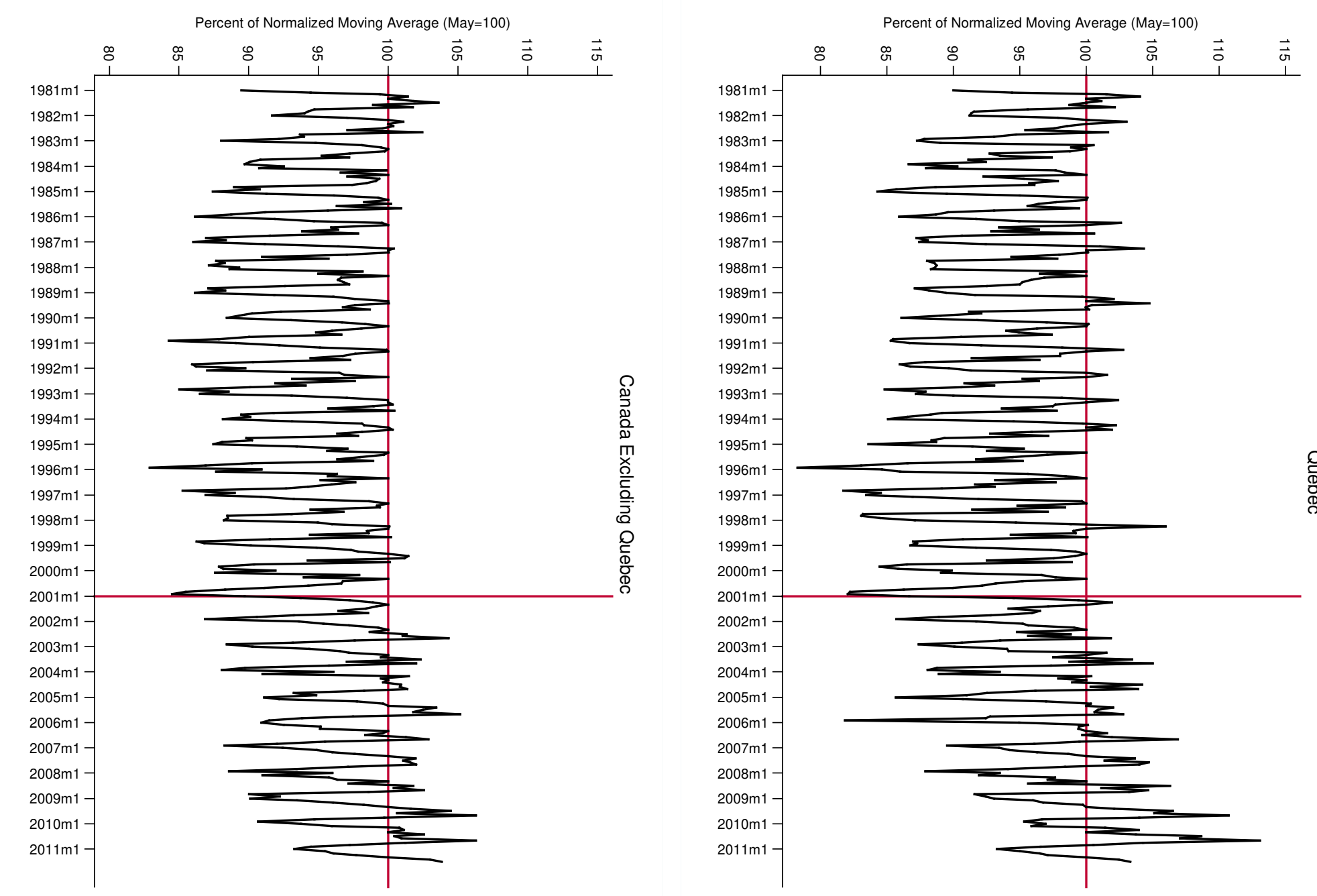


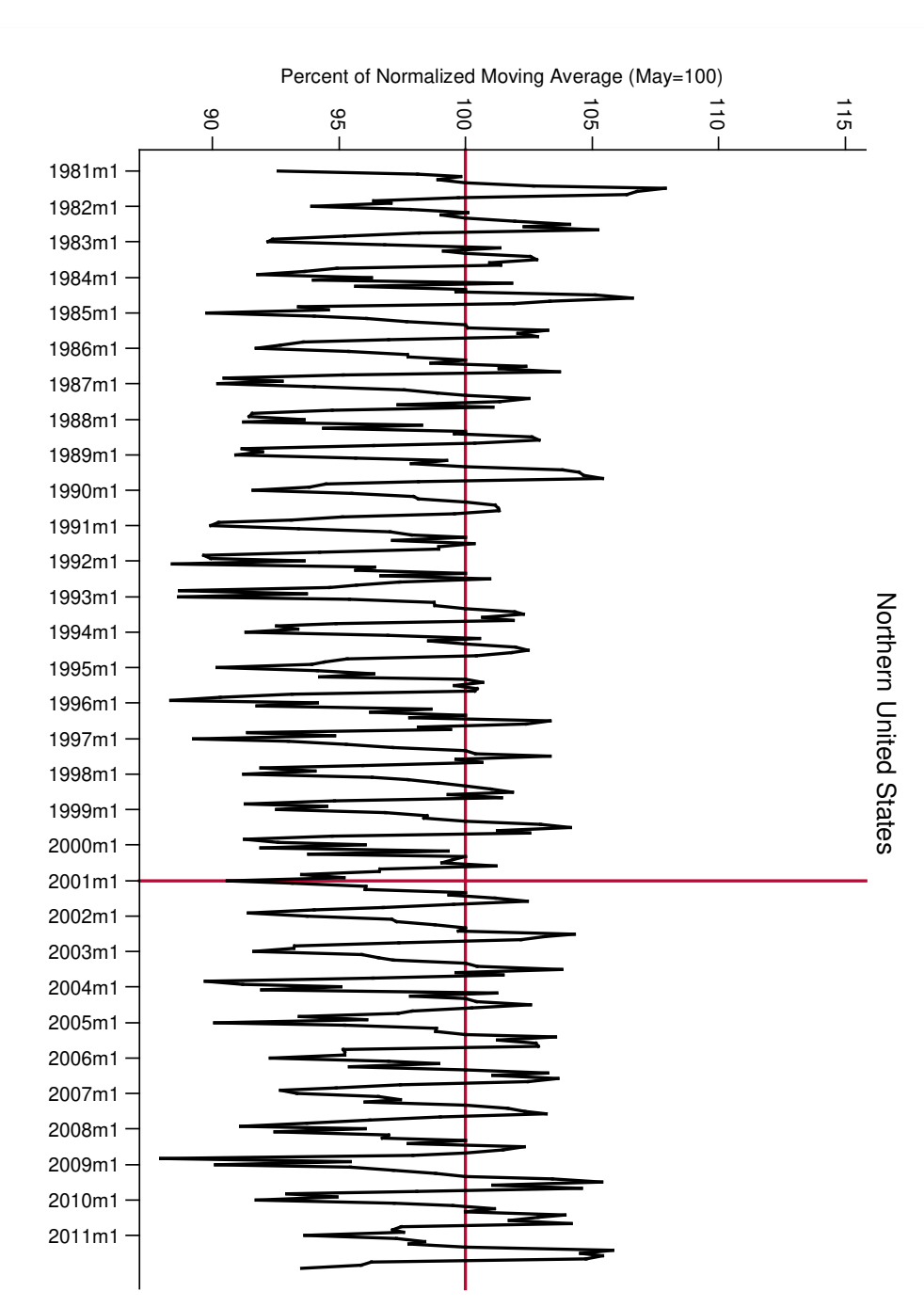


Figure 4: Actual Month of Birth. OLS Regression Coefficients, Pre- and Post- January 1, 2001, Canada and the northern United States

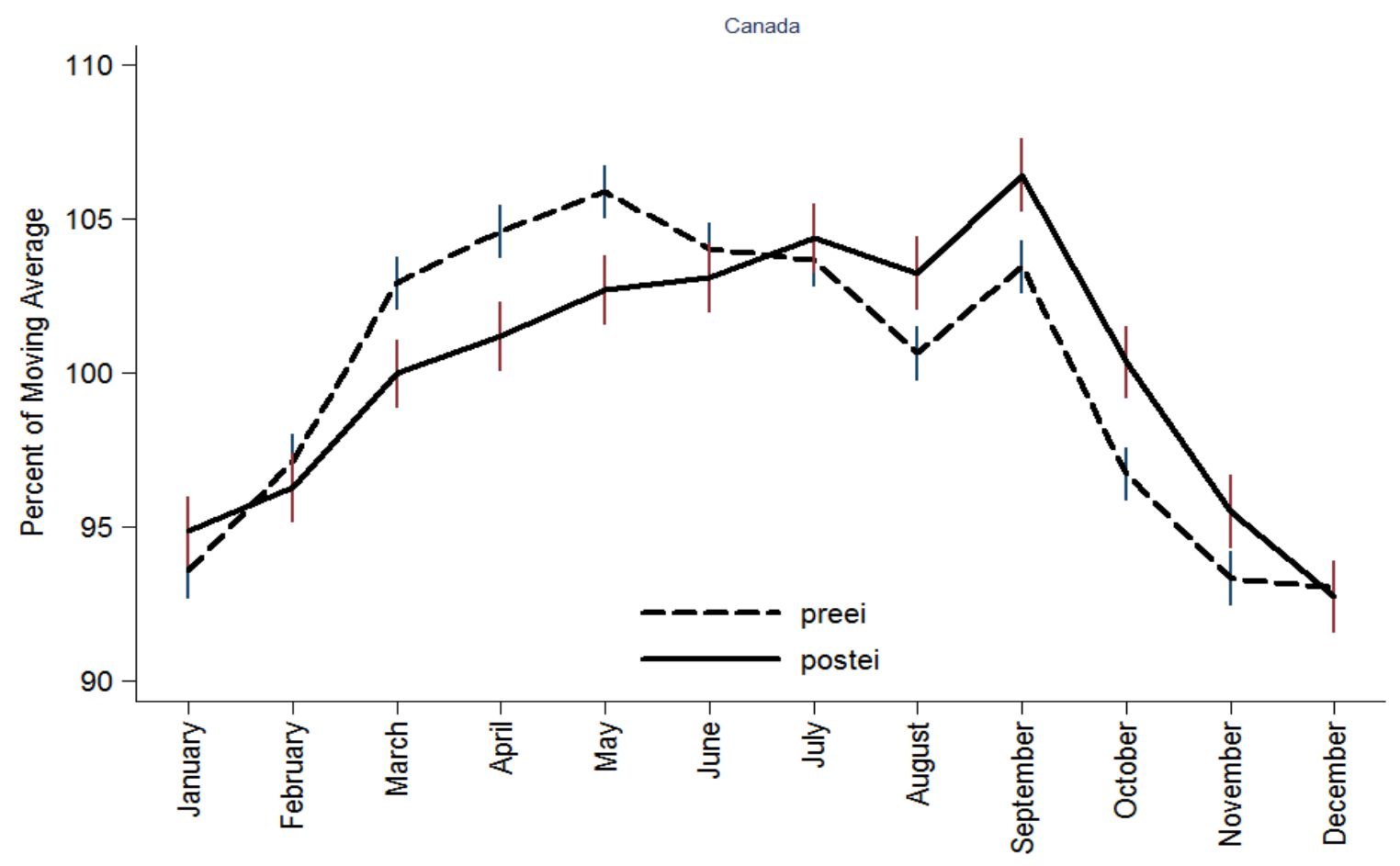

Actual Birth Month

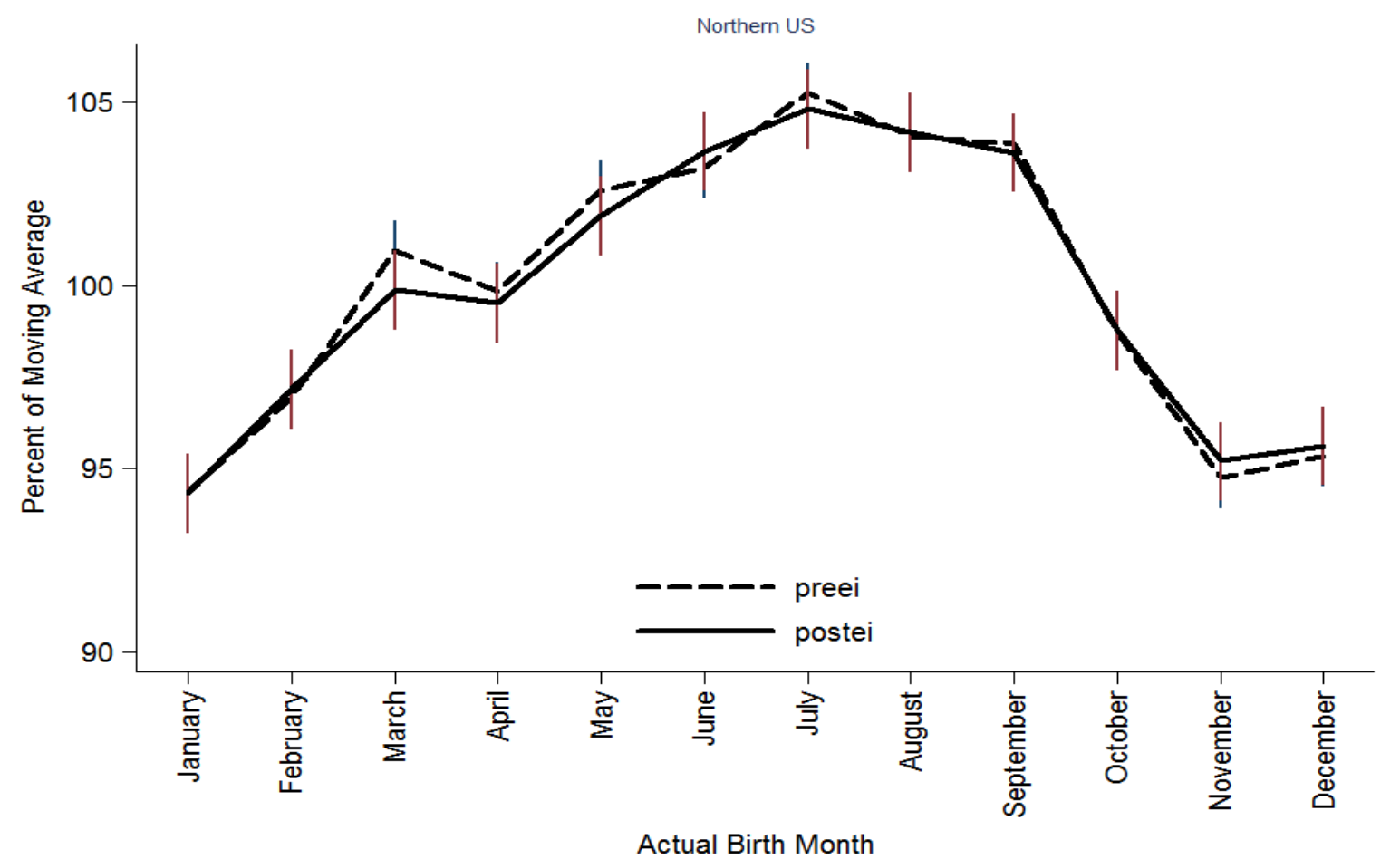


Figure 5: Expected Month of Birth. OLS Regression Coefficients, Pre- and Post- January 1, 2001, Canada and the northern United States

$$
\text { Canada }
$$

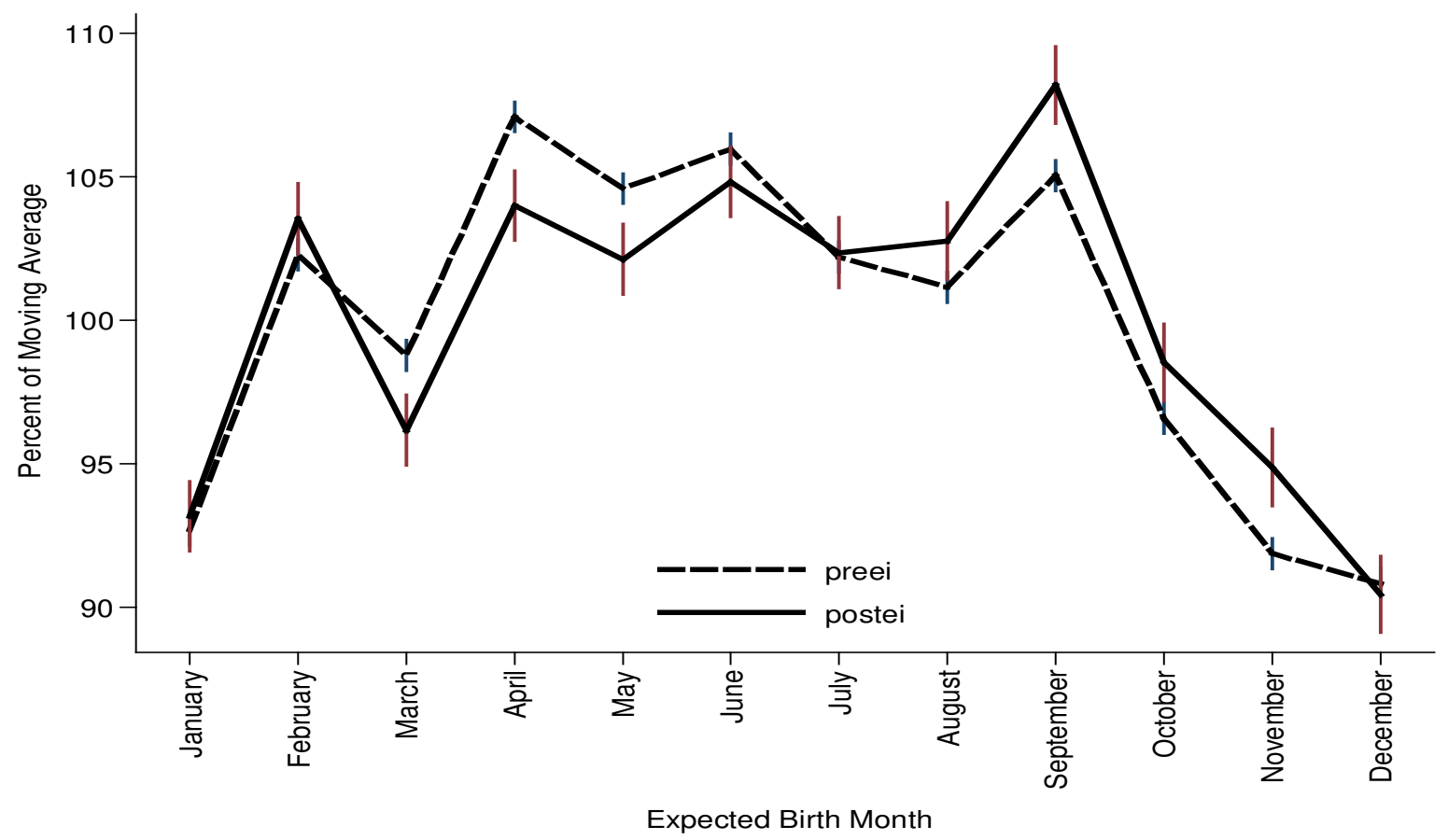

Northern US

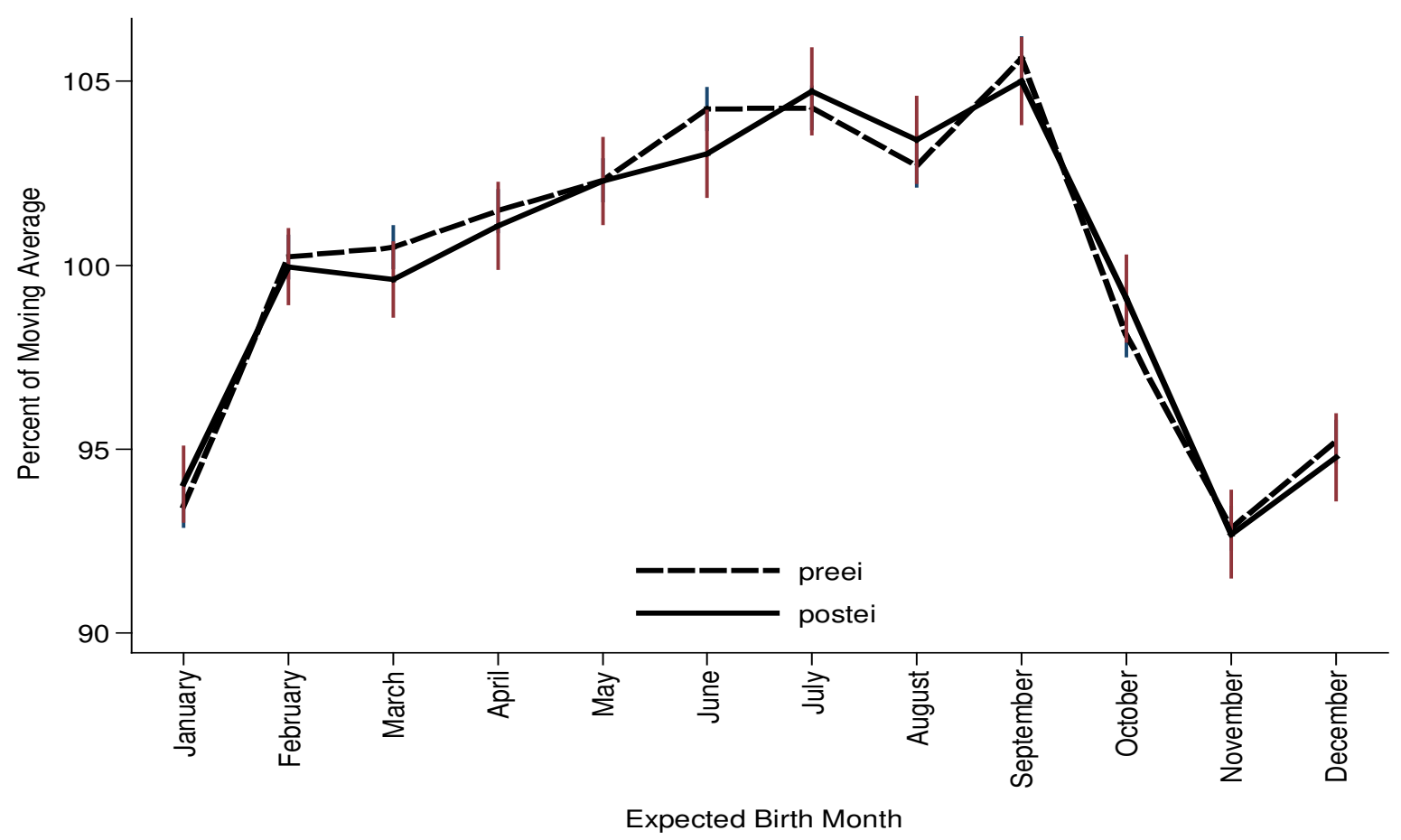


Figure 6: Expected Month of Birth. OLS Regression Coefficients, Pre- and Post- January 1, 2001, Canada, by subsample.
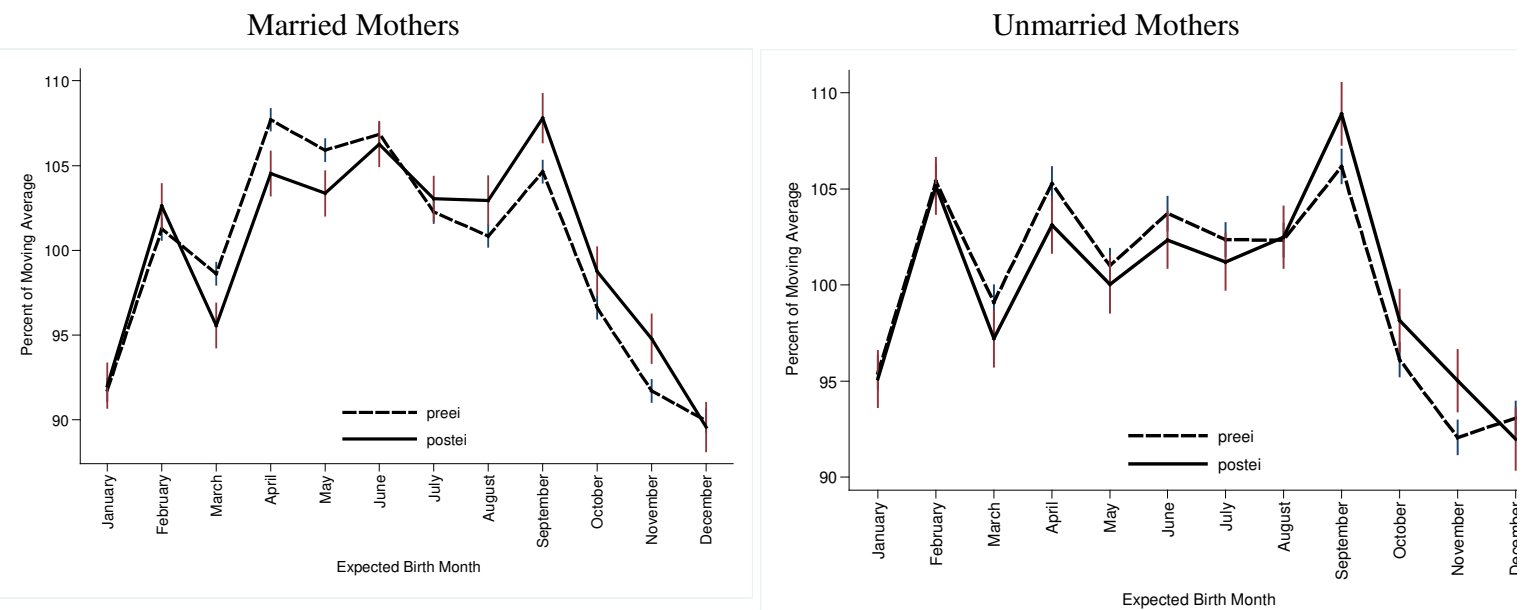

Married Mothers, 24 years and younger

Married Mothers, Aged 25-34
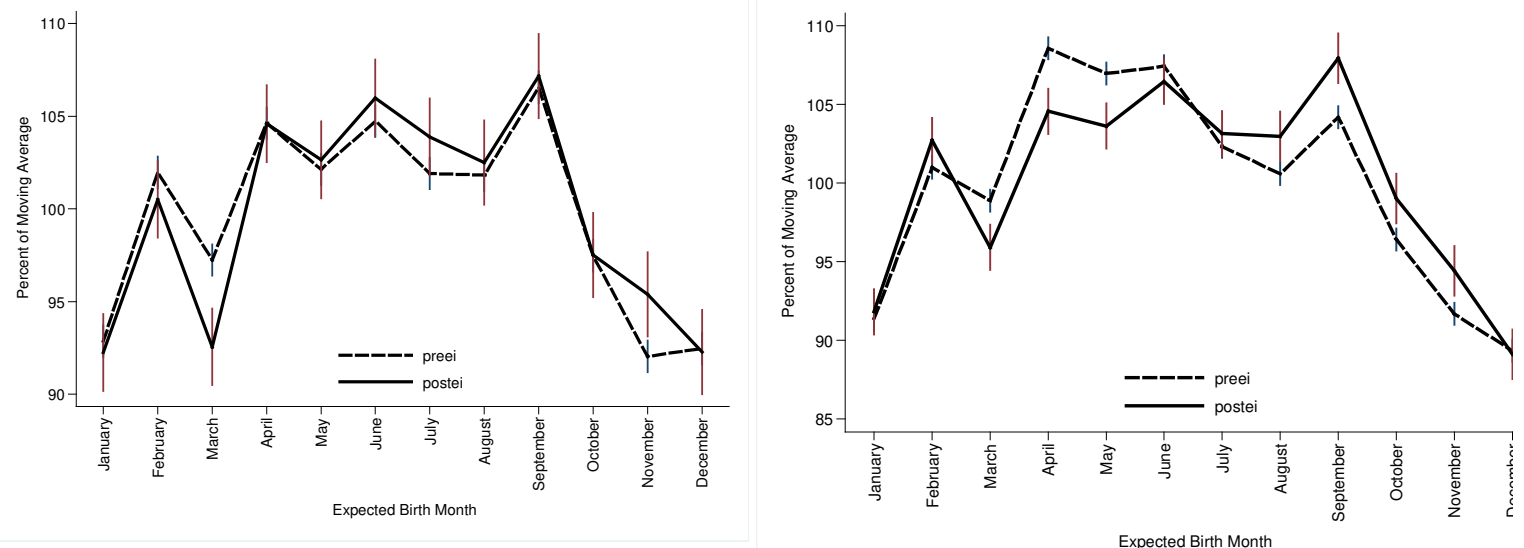

Married Mothers, 35 years and older

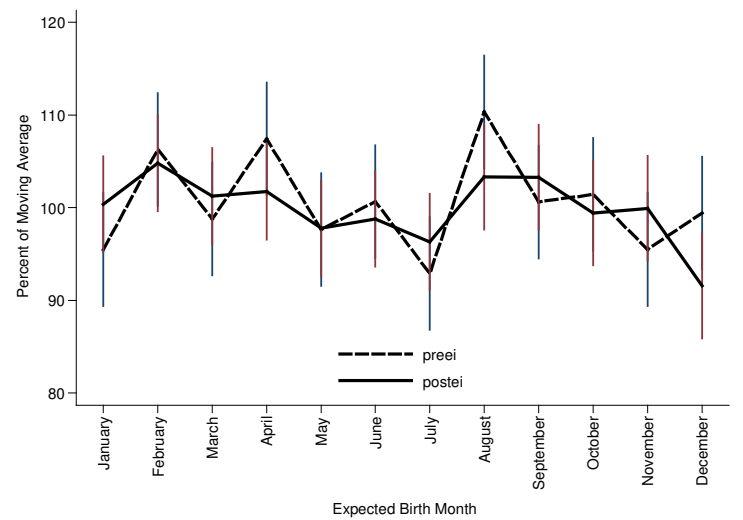


Figure 7a: Multinomial Logit Regression Results: Relative Risk Ratios, Probability of birth in month, relative to May.

Canada: Time controls only

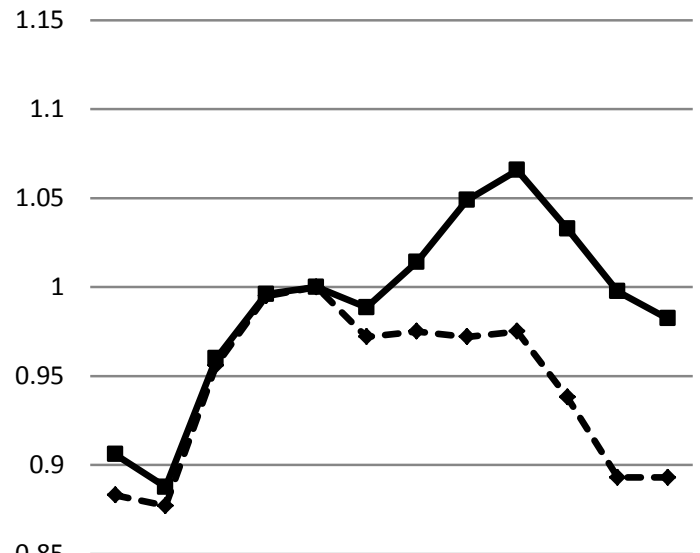

0.8

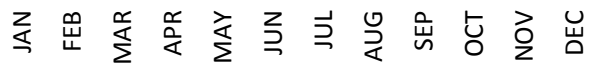

$$
\begin{aligned}
& \rightarrow \text { Post-El } \quad \text { - - Pre-El }
\end{aligned}
$$

Canada: With all controls

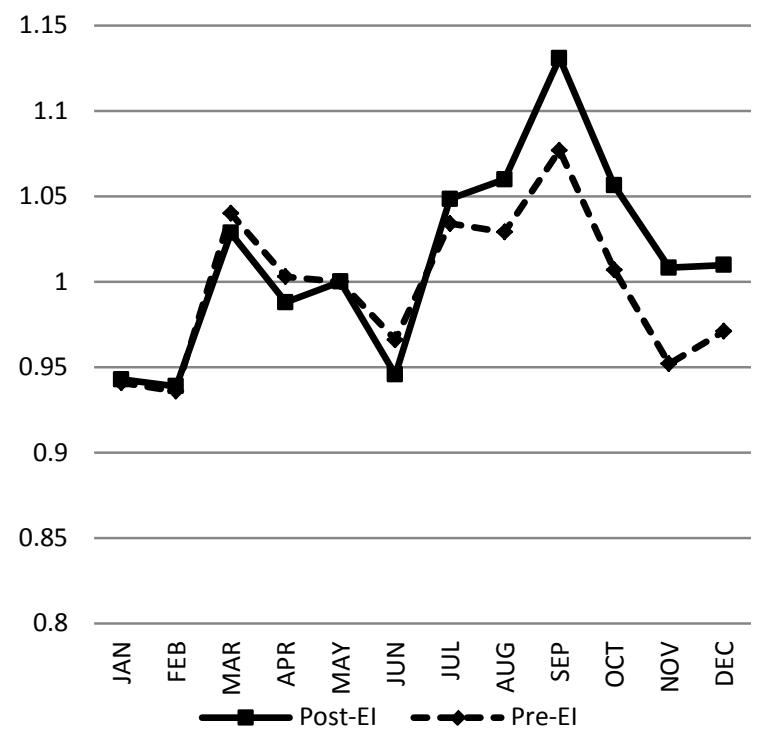

US: Time controls only
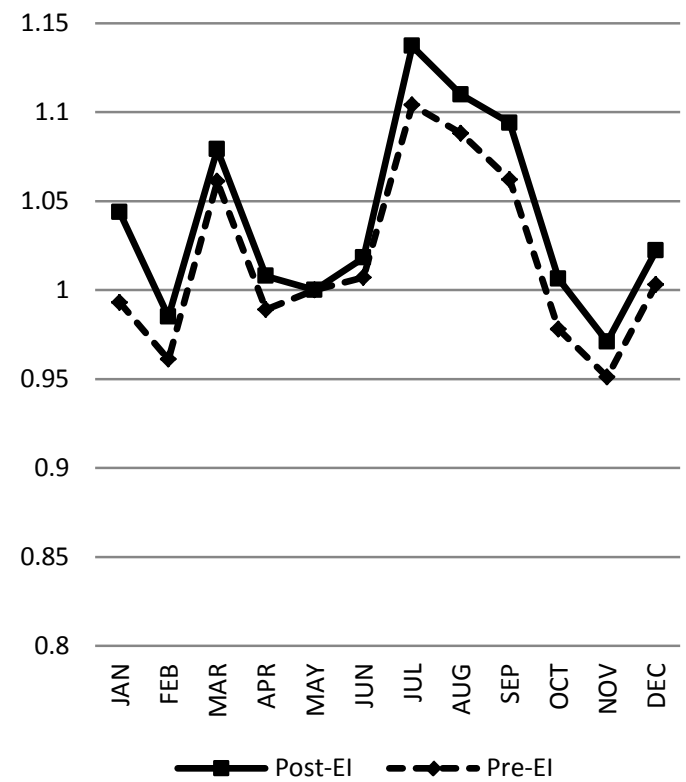

US: With all controls

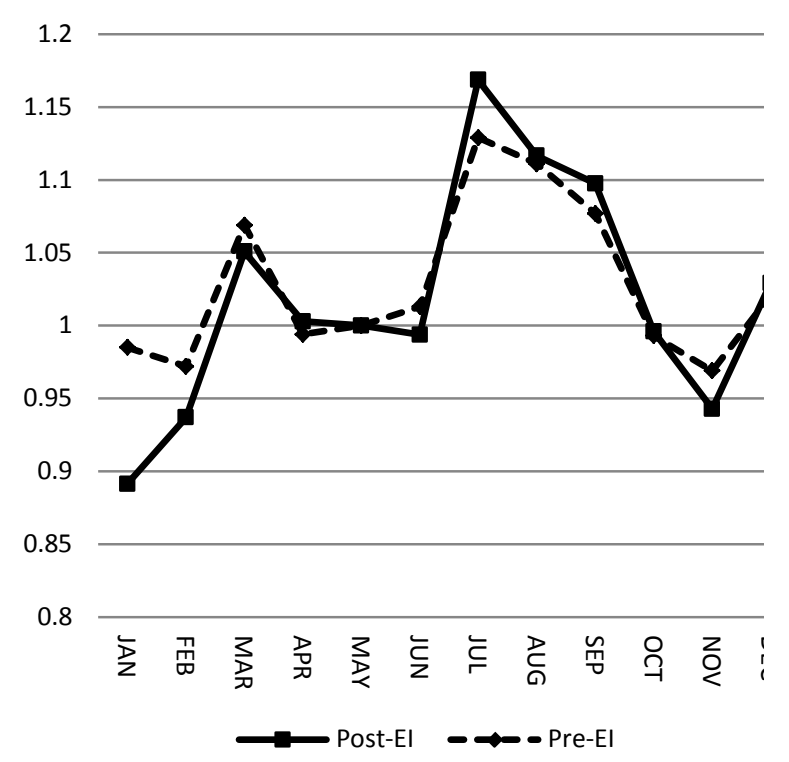


Figure 7b: Multinomial Logit Regression Results: Relative Risk Ratios, Probability of birth in month, relative to May.

Canada: With all controls, Effect on married women

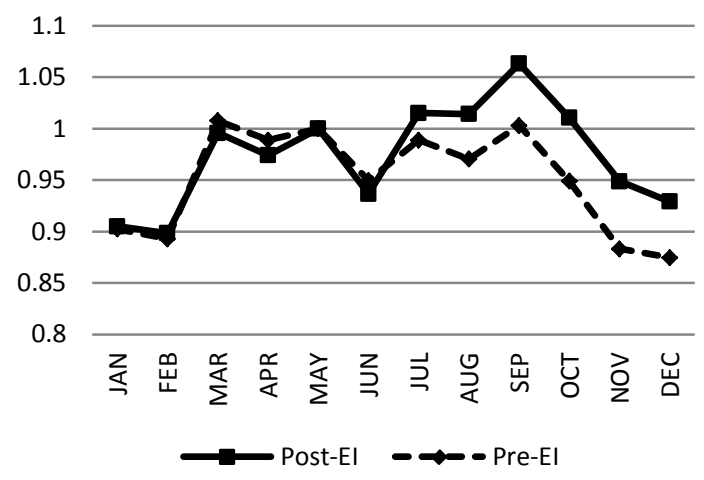

Canada: With all controls, Effect on unmarried women

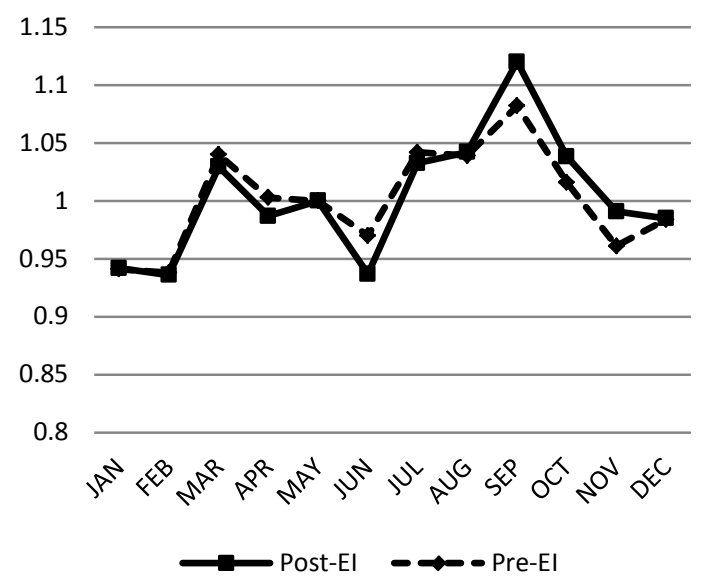

US: With all controls, effect on married women

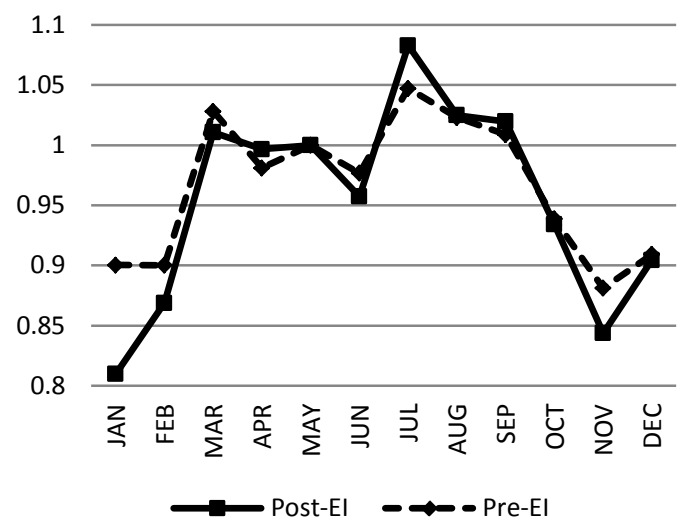

US: With all controls, effect on unmarried women

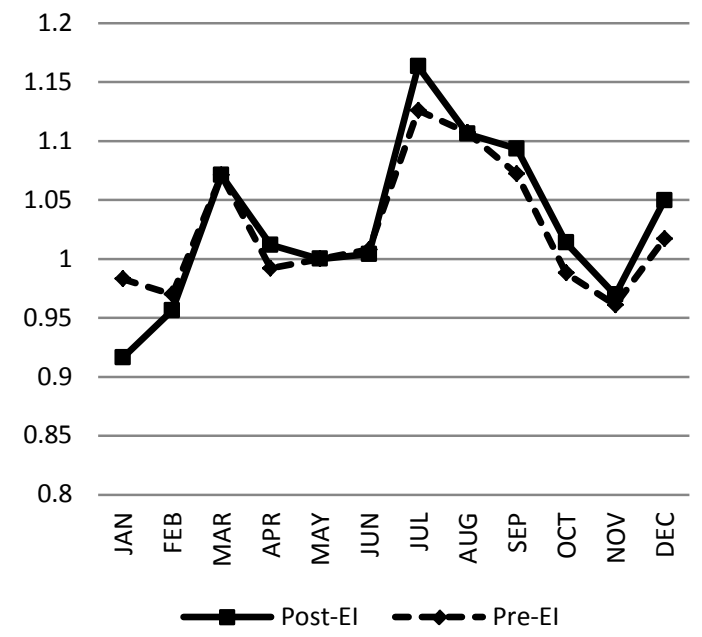


Figure 7c: Multinomial Logit Regression Results: Relative Risk Ratios, Probability of birth in month, relative to May.

Canada: With all controls, effect on women aged less than 24
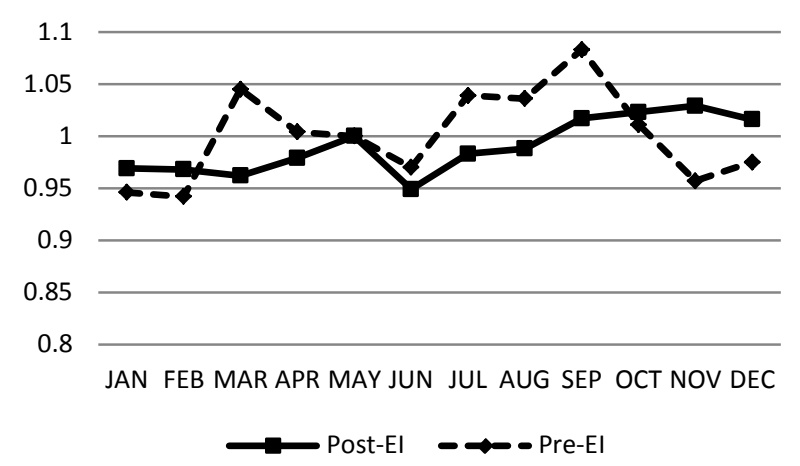

Canada: With all controls, effect on women aged 25-34

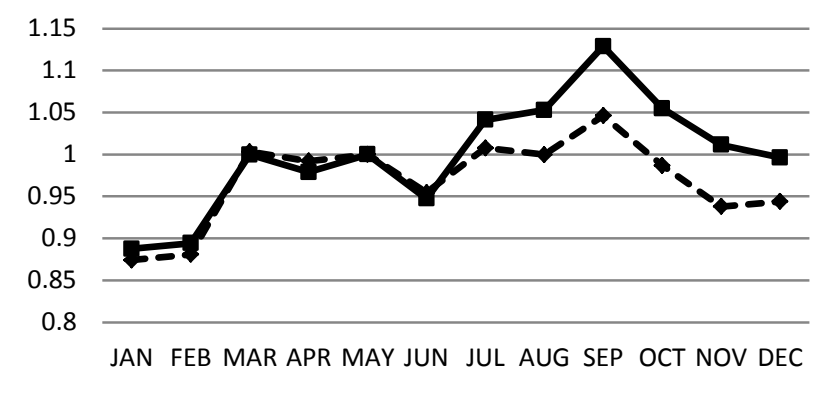

Canada: With all controls, effect on women aged 35 and up

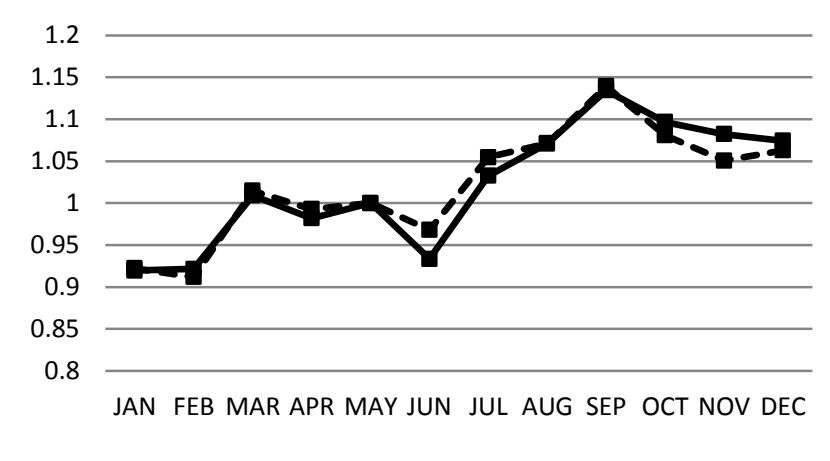




\section{References}

Anderson, B.A. and Silver, B.D. (1988) The effects of the registration system on the seasonality of births: The case of the Soviet Union. Population Studies 42, 303-320.

Baker, Michael and Kevin Milligan (2008) How does job protected maternity leave affect mothers' employment? Journal of Labor Economics, Vol. 26, No. 4, pp. 655-692.

Bedard, Kelly and Elizabeth Dhuey, The Persistence of Early Childhood Maturity: International Evidence of Long-Run Age Effects The Quarterly Journal of Economics

Vol. 121, No. 4 (Nov., 2006), pp. 1437-1472.

Bobak, M. and Gjonca, A. (2001) The seasonality of live birth is strongly influenced by socidemographic factors. Human Reproduction 16, 1512-1517.

Buckles, Kasey S. and Daniel M. Hungerman (2013) Season of Birth and Later Outcomes: Old Questions and New Answers. The Review of Economics and Statistics, Vol. 9, No, 3 ( July 2013), 711-724.

Canada (1999) Speech from the throne to open the $2^{\text {nd }}$ session of the 36th Parliament of Canada. Ottawa: Government of Canada. Retrieved from the Privy Council Office website: http://www.pcobcp.gc.ca/index.asp?lang=eng \&page=information \&sub=publications\&doc $=$ aarchives $/$ sftddt/1999-eng.htm

Cassels, P-G. (2002) Changing seasonality of births in Sweden 1900-1999. In Carling, J. (ed.) Nordic Demography: Trends and Differentials. Scandinavian Population Studies, vol. 13. Unipub forlag/Nordic Demographic Society, Oslo.

Cowgill, U.M. (1966) The Season of Birth in Man. Man 1(2), 232-240.

Currie, Janet and Hannes Schwandt. (2013) Within-mother analysis of seasonal patterns in health at birth. Proceedings of the National Academy of Science of the United States of America (PNAS) 110(30)12265-12270.

Dalen, P. (1968) Month of birth and schizophrenia. Acta psychiatrica Scandinavica 43(203) 5560 .

De Beer, J. (1997) Meeste kinderen in zomer geboren [Most children born in summer]. Maandstatistiek van de Bevolking 45(5), 6-9.

Department of Finance Canada (2000) The Budget Plan 2000. Retrieved from: http://fin.gc.ca/budget00/pdf/bpe.pdf 
Dickert-Conlin, S. and Chandra, A. (1999) Taxes and the timing of births. Journal of Political Economy 107(1), 161-177.

Dickert-Conlin, S. and Elder, T. (2010) Suburban Legend: School Cutoff Dates and the Timing of Births. Economics of Education Review 29(5), 826-841.

Finer, Lawrence B. and Stanley K. Henshaw (2006) Disparities in Rates of Unintended Pregnancy in the United States, 1994-2001. Perspectives on Social and Reproductive Health, Vol. 38, No. 2 (June 2006), 90-96.

Finer, Lawrence B. and Mia R. Zolna (2011) Unintended pregnancy in the United States: Incidence and disparities, 2006. Contraception, Vol 84 (2011), 478-485.

Foster, Russell G. and Till Roenneberg (2008) Human responses to the Geophysical Daily, Annual and Lunar Cycles. Current Biology 18, R784-R794.

Gans, J.S. and Leigh, A. (2009) Born on the First of July: An (Un)natural Experiment in Birth Timing. Journal of Public Economics 93(1-2), 246-263.

Haandrikman, K. and Van Wissen, L.J.G. (2008) Effects of the fertility transition on birth seasonality in the Netherlands. Journal of Biosocial Science 40(5), 655-672.

Halli, S.S. (1989) The seasonality of births in Canada. Journal of Biosocial Science 21(3), 321327.

Hanratty, M. and Trzcinski, E. (2009) Who Benefits from Paid Family Leave? Impact of Expansions in Canadian Paid Family Leave on Maternal Employment and Transfer Income. Journal of Population Economics 22, 693-711.

Henshaw, Stanley (1998) Unintended Pregnancy in the United States. Family Planning Perspectives, Vol. 30, No. 1 (Jan - Feb 1998), 24-29.

Huntington, E. (1938) Season of birth. New York: John Wiley and Sons.

Kihlbom, M., and Johansson, S.E. (2004) Month of birth, socioeconomic background and development in Swedish men. Journal of Biosocial Science 36(5), 561-571.

Kureishi, W., and Wakabayashi, M. (2008) Taxing the Stork. National Tax Journal 61(2), 167187.

Lam, D.A. and Miron, J.A. (1994) Global patterns of seasonal variation in human fertility. Annals of the New York Academy of Sciences 709, 9-28.

LaLumia, S., Sallee, J.M., and Turner, N. (2015) New Evidence on Taxes and the Timing of Birth. American Economic Journal: Economic Policy 7(2), 258-293. 
Leigh, A., and Ryan, C. (2008) Estimating returns to education using different natural experiment techniques. Economics of Education Review 27, 149-160.

Leiss, J.K., and Suchindran, C.M. (1993) Age and season of birth in sudden infant death syndrome in North Caroline, 1982-1987: No interaction. American Journal of Epidemology 137(2), 207-212.

Marshall, K. (2003) Benefiting from extended parental leave. Perspectives on Labour and Income 4(3), 5-11.

(2008) Fathers' use of paid parental leave. Perspectives on Labour and Income June, 5-

14.

(2010) Employer top-ups. Perspectives on Labour and Income February, 5-12.

Neugart, M. and Ohlsson, H. (2013) Economic Incentives and the Timing of Births: Evidence from the German Parental Benefit Regorm of 2007. Journal of Population Economics 26(1), 87108.

Puhani, P.A., and Weber, A.M. (2008) Does the early bird catch the worm? Instrumental variable estimation of educational effects of age of school entry in Germany. In Dustmann, C.,

Fitzenberger, B., and Machin, S. (eds.) The Economics of Education and Training. Heidelberg: Physcica-Verlag.

Pulkingham, J. and Van Der Gaag, T. (2004) Maternity/Parental leave provisions in Canada: We've come a long way. But there's further to go. Canadian Woman Studies/Les Cahiers de la Femme 23(3-4), 116-125.

Procopio, M., Marriott, P.K., and Williams, P. (1997) Season of birth: aetiological implications for epilepsy. Seizure 6(2), 99-105.

Saha, S., Chant, D.C., Welham, J.L., McGrath, J.J., 2006. The incidence and prevalence of schizophrenia varies with latitude. Acta Neurologica Scandinavia 114, 36-39.

Samuelsson, U., Johansson, C., and Ludvigsson, J. (1999) Month of birth and risk of developing insulin dependent diabetes in south east Sweden. Archives of Disease in Childhood 81(2), 143146.

Siever, D. A. (1985) Trend and variation in the seasonality of US fertility, 1947-1976.

Demography 22, 89-100.

Templer, D.I., Trent, N.H., Spencer, D.A, Trent, A., Corgiat, M.D., Mortensen, P.B., and Gorton, M. Season of birth in multiple sclerosis. Acta Neurologica Scandinavia 85(2), 107-109 
Torrey, E.F., Miller, J., Rawlings, R., Yolken, R.H., 1997. Seasonality of births in schizophrenia and bipolar disorder: a review of the literature. Schizophrenia Research 28, 1-38.

Trovato, F. and Odynak, D. (1993) The seasonality of births in Canada and the provinces, 18811989: Theory and analysis. Canadian Studies in Population 20, 1-41.

Van de Kaa, D. J. (1987) Europe's second demographic transition. Population Bulletin 42(1).

Werschler, T. and Halli, S. (1992) The seasonality of births in Canada: A comparison with the northern United States. Population and Environment 14, 85-94.

Willer, C.J., Dyment, D.A., Sadovnick, A.D., Rothwell, P.M., Murray, T.J., Ebers, G.C., 2005. Timing of birth and risk of multiple sclerosis: population based study. British Medical Journal $330,120$. 


\section{Appendix}

Table A.1: Actual Month of Birth. OLS Regression Coefficients, Pre- and Post- January 1, 2001, Canada and the northern United States

\begin{tabular}{|c|c|c|c|c|}
\hline & $\begin{array}{c}\text { Canada } \\
\text { Pre-E.I. Reform }\end{array}$ & $\begin{array}{c}\text { Canada } \\
\text { Post-E.I. Reform }\end{array}$ & $\begin{array}{c}\text { Northern US } \\
\text { Pre-E.I. Reform }\end{array}$ & $\begin{array}{c}\text { Northern US } \\
\text { Post-E.I. Reform }\end{array}$ \\
\hline January & $\begin{array}{c}93.57 \\
(92.72-94.42)\end{array}$ & $\begin{array}{c}94.87 \\
(93.77-95.97)\end{array}$ & $\begin{array}{c}94.36 \\
(93.57-95.16)\end{array}$ & $\begin{array}{c}94.33 \\
(93.27-95.39)\end{array}$ \\
\hline February & $\begin{array}{c}97.14 \\
(96.29-97.99)\end{array}$ & $\begin{array}{c}96.27 \\
(95.17-97.38)\end{array}$ & $\begin{array}{c}96.94 \\
(96.14-97.74)\end{array}$ & $\begin{array}{c}97.17 \\
(96.11-98.23)\end{array}$ \\
\hline March & $\begin{array}{c}102.94 \\
(102.09-103.79)\end{array}$ & $\begin{array}{c}99.98 \\
(98.88-101.09)\end{array}$ & $\begin{array}{c}100.95 \\
(100.15-101.74)\end{array}$ & $\begin{array}{c}99.88 \\
(98.82-100.94)\end{array}$ \\
\hline April & $\begin{array}{c}104.61 \\
(103.77-105.46)\end{array}$ & $\begin{array}{c}101.21 \\
(100.11-102.32)\end{array}$ & $\begin{array}{c}99.84 \\
(99.04-100.63)\end{array}$ & $\begin{array}{c}99.51 \\
(98.45-100.57)\end{array}$ \\
\hline May & $\begin{array}{c}105.89 \\
(105.04-106.74)\end{array}$ & $\begin{array}{c}102.70 \\
(101.59-103.80)\end{array}$ & $\begin{array}{c}102.58 \\
(101.79-103.38)\end{array}$ & $\begin{array}{c}101.90 \\
(100.84-102.96)\end{array}$ \\
\hline June & $\begin{array}{c}104.03 \\
(103.18-104.88)\end{array}$ & $\begin{array}{c}103.11 \\
(102.00-104.21)\end{array}$ & $\begin{array}{c}103.20 \\
(102.40-104.00)\end{array}$ & $\begin{array}{c}103.65 \\
(102.59-104.71)\end{array}$ \\
\hline July & $\begin{array}{c}103.68 \\
(102.83-104.53)\end{array}$ & $\begin{array}{c}104.37 \\
(103.27-105.47)\end{array}$ & $\begin{array}{c}105.25 \\
(104.46-106.05)\end{array}$ & $\begin{array}{c}104.81 \\
(103.75-105.87)\end{array}$ \\
\hline August & $\begin{array}{c}100.65 \\
(99.80-101.50)\end{array}$ & $\begin{array}{c}103.25 \\
(102.10-104.41)\end{array}$ & $\begin{array}{c}104.06 \\
(103.26-104.86)\end{array}$ & $\begin{array}{c}104.18 \\
(103.12-105.23)\end{array}$ \\
\hline September & $\begin{array}{c}103.46 \\
(102.61-104.31)\end{array}$ & $\begin{array}{c}106.44 \\
(105.28-107.60)\end{array}$ & $\begin{array}{c}103.87 \\
(103.07-104.66)\end{array}$ & $\begin{array}{c}103.62 \\
(102.56-104.68)\end{array}$ \\
\hline October & $\begin{array}{c}96.72 \\
(95.87-97.57)\end{array}$ & $\begin{array}{c}100.37 \\
(99.21-101.53)\end{array}$ & $\begin{array}{c}98.71 \\
(97.91-99.51)\end{array}$ & $\begin{array}{c}98.77 \\
(97.71-99.83)\end{array}$ \\
\hline November & $\begin{array}{c}93.34 \\
(92.49-94.18)\end{array}$ & $\begin{array}{c}95.51 \\
(94.35-96.66)\end{array}$ & $\begin{array}{c}94.76 \\
(93.96-95.55)\end{array}$ & $\begin{array}{c}95.21 \\
(94.15-96.27)\end{array}$ \\
\hline December & $\begin{array}{c}93.02 \\
(92.18-93.87)\end{array}$ & $\begin{array}{c}92.74 \\
(91.58-93.90)\end{array}$ & $\begin{array}{c}95.34 \\
(94.54-96.14)\end{array}$ & $\begin{array}{c}95.63 \\
(94.57-96.69)\end{array}$ \\
\hline Observations & 240 & 127 & 240 & 132 \\
\hline
\end{tabular}


Table A.2: Actual Month of Birth. OLS Regression Coefficients, Pre- and Post- January 1, 2001, Quebec and the Rest of Canada

\begin{tabular}{|c|c|c|c|c|}
\hline & $\begin{array}{c}\text { Canada, Excluding Quebec } \\
\text { Pre-E.I. Reform }\end{array}$ & $\begin{array}{c}\text { Canada, Excluding Quebec } \\
\text { Post-E.I. Reform }\end{array}$ & $\begin{array}{c}\text { Quebec } \\
\text { Pre-E.I. Reform }\end{array}$ & $\begin{array}{c}\text { Quebec } \\
\text { Post-E.I. Reform }\end{array}$ \\
\hline \multirow[t]{2}{*}{ January } & 93.79 & 95.07 & 92.82 & 94.19 \\
\hline & $(92.93-94.65)$ & $(94.00-96.14)$ & $(91.80-93.84)$ & $(92.59-95.79)$ \\
\hline \multirow[t]{2}{*}{ February } & 97.20 & 96.23 & 96.93 & 96.42 \\
\hline & (96.34 - 98.06) & $(95.16-97.30)$ & $(95.91-97.95)$ & $(94.82-98.03)$ \\
\hline \multirow[t]{2}{*}{ March } & 102.54 & 99.99 & 104.23 & 99.98 \\
\hline & $(101.68-103.40)$ & $(98.92-101.06)$ & $(103.21-105.25)$ & $(98.37-101.58)$ \\
\hline \multirow[t]{2}{*}{ April } & 103.87 & 100.98 & 107.05 & 102.04 \\
\hline & $(103.01-104.73)$ & $(99.91-102.05)$ & $(106.03-108.07)$ & $(100.43-103.64)$ \\
\hline \multirow[t]{2}{*}{ May } & 105.73 & 102.81 & 106.43 & 102.35 \\
\hline & $(104.87-106.58)$ & $(101.74-103.88)$ & $(105.41-107.45)$ & $(100.75-103.95)$ \\
\hline \multirow[t]{2}{*}{ June } & 104.10 & 103.36 & 103.78 & 102.25 \\
\hline & $(103.24-104.96)$ & $(102.29-104.43)$ & $(102.76-104.80)$ & $(100.65-103.85)$ \\
\hline \multirow[t]{2}{*}{ July } & 103.90 & 104.23 & 102.95 & 104.83 \\
\hline & $(103.04-104.76)$ & $(103.16-105.30)$ & $(101.93-103.97)$ & $(103.23-106.44)$ \\
\hline \multirow[t]{2}{*}{ August } & 100.83 & 103.13 & 100.05 & 103.66 \\
\hline & $(99.97-101.69)$ & $(102.01-104.25)$ & $(99.03-101.07)$ & $(101.98-105.35)$ \\
\hline \multirow[t]{2}{*}{ September } & 103.45 & 106.15 & 103.51 & 107.43 \\
\hline & $(102.59-104.31)$ & $(105.02-107.27)$ & $(102.49-104.53)$ & $(105.74-109.11)$ \\
\hline \multirow[t]{2}{*}{ October } & 96.96 & 100.29 & 95.91 & 100.61 \\
\hline & $(96.10-97.82)$ & $(99.17-101.41)$ & $(94.89-96.93)$ & $(98.92-102.29)$ \\
\hline \multirow[t]{2}{*}{ November } & 93.51 & 95.50 & 92.78 & 95.51 \\
\hline & $(92.65-94.37)$ & $(94.38-96.62)$ & $(91.76-93.80)$ & $(93.83-97.19)$ \\
\hline \multirow[t]{2}{*}{ December } & 93.30 & 93.02 & 92.11 & 91.77 \\
\hline & $(92.44-94.16)$ & $(91.90-94.14)$ & $(91.09-93.13)$ & $(90.08-93.45)$ \\
\hline Observations & 240 & 127 & 240 & 127 \\
\hline
\end{tabular}

Note: $95 \%$ Confidence Intervals provided in parentheses. 
Table A.3: Expected Month of Birth. OLS Regression Coefficients, Pre- and Post- January 1, 2001, Canada and the northern United States

\begin{tabular}{|c|c|c|c|c|}
\hline & $\begin{array}{c}\text { Canada } \\
\text { Pre-E.I. Reform }\end{array}$ & $\begin{array}{c}\text { Canada } \\
\text { Post-E.I. Reform }\end{array}$ & $\begin{array}{c}\text { Northern US } \\
\text { Pre-E.I. Reform }\end{array}$ & $\begin{array}{c}\text { Northern US } \\
\text { Post-E.I. Reform }\end{array}$ \\
\hline January & $\begin{array}{c}92.7 \\
(92.16-93.23)\end{array}$ & $\begin{array}{c}93.17 \\
(91.95-94.38)\end{array}$ & $\begin{array}{c}93.46 \\
(92.89-94.03)\end{array}$ & $\begin{array}{c}94.05 \\
(93.07-95.03)\end{array}$ \\
\hline February & $\begin{array}{c}102.3 \\
(101.76-102.83)\end{array}$ & $\begin{array}{c}103.5 \\
(102.28-104.71)\end{array}$ & $\begin{array}{c}100.2 \\
(99.63-100.77)\end{array}$ & $\begin{array}{c}99.96 \\
(98.98-100.94)\end{array}$ \\
\hline March & $\begin{array}{c}98.79 \\
(98.25-99.32)\end{array}$ & $\begin{array}{c}96.18 \\
(94.96-97.39)\end{array}$ & $\begin{array}{c}100.5 \\
(99.93-101.07)\end{array}$ & $\begin{array}{c}99.61 \\
(98.63-100.59)\end{array}$ \\
\hline April & $\begin{array}{c}107.1 \\
(106.56-107.63)\end{array}$ & $\begin{array}{c}104 \\
(102.78-105.21)\end{array}$ & $\begin{array}{c}101.5 \\
(100.93-102.07)\end{array}$ & $\begin{array}{c}101.1 \\
(99.97-102.23)\end{array}$ \\
\hline May & $\begin{array}{c}104.6 \\
(104.06-105.13)\end{array}$ & $\begin{array}{c}102.1 \\
(100.88-103.31)\end{array}$ & $\begin{array}{c}102.3 \\
(101.73-102.87)\end{array}$ & $\begin{array}{c}102.3 \\
(101.17-103.43)\end{array}$ \\
\hline June & $\begin{array}{c}106 \\
(105.46-106.53)\end{array}$ & $\begin{array}{c}104.8 \\
(103.58-106.01)\end{array}$ & $\begin{array}{c}104.2 \\
(103.63-104.77)\end{array}$ & $\begin{array}{c}103 \\
(101.87-104.13)\end{array}$ \\
\hline July & $\begin{array}{c}102.2 \\
(101.66-102.73)\end{array}$ & $\begin{array}{c}102.4 \\
(101.18-103.61)\end{array}$ & $\begin{array}{c}104.3 \\
(103.73-104.87)\end{array}$ & $\begin{array}{c}104.7 \\
(103.57-105.83)\end{array}$ \\
\hline August & $\begin{array}{c}101.2 \\
(100.66-101.73)\end{array}$ & $\begin{array}{c}102.8 \\
(101.46-104.13)\end{array}$ & $\begin{array}{c}102.7 \\
(102.13-103.27)\end{array}$ & $\begin{array}{c}103.4 \\
(102.27-104.53)\end{array}$ \\
\hline September & $\begin{array}{c}105 \\
(104.46-105.53)\end{array}$ & $\begin{array}{c}108.2 \\
(106.86-109.53)\end{array}$ & $\begin{array}{c}105.6 \\
(105.03-106.17)\end{array}$ & $\begin{array}{c}105 \\
(103.87-106.13)\end{array}$ \\
\hline October & $\begin{array}{c}96.59 \\
(96.05-97.12)\end{array}$ & $\begin{array}{c}98.54 \\
(97.2-99.87)\end{array}$ & $\begin{array}{c}98.09 \\
(97.52-98.66)\end{array}$ & $\begin{array}{c}99.09 \\
(97.96-100.22)\end{array}$ \\
\hline November & $\begin{array}{c}91.88 \\
(91.34-92.41)\end{array}$ & $\begin{array}{c}94.87 \\
(93.53-96.2)\end{array}$ & $\begin{array}{c}92.85 \\
(92.28-93.42)\end{array}$ & $\begin{array}{c}92.69 \\
(91.56-93.82)\end{array}$ \\
\hline December & $\begin{array}{c}90.84 \\
(90.3-91.37)\end{array}$ & $\begin{array}{c}90.46 \\
(89.12-91.79)\end{array}$ & $\begin{array}{c}95.2 \\
(94.63-95.77)\end{array}$ & $\begin{array}{c}94.77 \\
(93.64-95.9)\end{array}$ \\
\hline Observations & 240 & 67 & 240 & 39 \\
\hline
\end{tabular}


Table A.4: Expected Month of Birth. Multinomial Logit Model. Relative Risk Ratios, Probability of birth in the month relative to May, Pre- and Post- January 1, 2001, Canada and the northern United States

\begin{tabular}{|c|c|c|c|c|c|c|c|c|c|c|c|c|}
\hline & Jan & Feb & Mar & Apr & May & Jun & Jul & Aug & Sep & Oct & Nov & Dec \\
\hline \multicolumn{13}{|c|}{ Canada: Time Trend Only } \\
\hline Post 2000 Indicator & $\begin{array}{l}1.026 * * * \\
(0.00579)\end{array}$ & $\begin{array}{c}1.012 * * \\
(0.00571)\end{array}$ & $\begin{array}{c}1.004 \\
(0.00560)\end{array}$ & $\begin{array}{c}1.001 \\
(0.00552)\end{array}$ & & $\begin{array}{l}1.017 * * * \\
(0.00560)\end{array}$ & $\begin{array}{l}1.040 * * * \\
(0.00572)\end{array}$ & $\begin{array}{l}1.079 * * * \\
(0.00594)\end{array}$ & $\begin{array}{l}1.093 * * * \\
(0.00600)\end{array}$ & $\begin{array}{l}1.101 * * * \\
(0.00613)\end{array}$ & $\begin{array}{l}1.117 * * * \\
(0.00629)\end{array}$ & $\begin{array}{l}1.100 * * * \\
(0.00625)\end{array}$ \\
\hline Constant & $\begin{array}{l}0.883 * * * \\
(0.00303)\end{array}$ & $\begin{array}{l}0.877 * * * \\
(0.00302)\end{array}$ & $\begin{array}{l}0.956 * * * \\
(0.00323)\end{array}$ & $\begin{array}{c}0.995 \\
(0.00332)\end{array}$ & & $\begin{array}{l}0.972 * * * \\
(0.00326)\end{array}$ & $\begin{array}{l}0.975 * * * \\
(0.00327)\end{array}$ & $\begin{array}{l}0.972 * * * \\
(0.00326)\end{array}$ & $\begin{array}{l}0.975 * * * \\
(0.00327)\end{array}$ & $\begin{array}{l}0.938 * * * \\
(0.00318)\end{array}$ & $\begin{array}{l}0.893 * * * \\
(0.00307)\end{array}$ & $\begin{array}{l}0.893 * * * * \\
(0.00307)\end{array}$ \\
\hline \multicolumn{13}{|c|}{ US: Time Trend Only } \\
\hline Post 2000 Indicator & $\begin{array}{l}1.051 * * * \\
(0.00378)\end{array}$ & $\begin{array}{l}1.025 * * * \\
(0.00374)\end{array}$ & $\begin{array}{l}1.017 * * * \\
(0.00363)\end{array}$ & $\begin{array}{l}1.019 * * * \\
(0.00366)\end{array}$ & & $\begin{array}{l}1.011 * * * \\
(0.00360)\end{array}$ & $\begin{array}{l}1.030 * * * \\
(0.00363)\end{array}$ & $\begin{array}{l}1.020 * * * \\
(0.00360)\end{array}$ & $\begin{array}{l}1.030 * * * \\
(0.00366)\end{array}$ & $\begin{array}{l}1.029 * * * \\
(0.00369)\end{array}$ & $\begin{array}{l}1.021^{* * * *} \\
(0.00371)\end{array}$ & $\begin{array}{l}1.019^{* * * *} \\
(0.00369)\end{array}$ \\
\hline Constant & $\begin{array}{c}0.993 * \\
(0.00398)\end{array}$ & $\begin{array}{l}0.961 * * * \\
(0.00389)\end{array}$ & $\begin{array}{l}1.061 * * * \\
(0.00420)\end{array}$ & $\begin{array}{l}0.989 * * * \\
(0.00396)\end{array}$ & & $\begin{array}{c}1.007 * \\
(0.00402)\end{array}$ & $\begin{array}{l}1.104 * * * \\
(0.00433)\end{array}$ & $\begin{array}{l}1.088 * * * \\
(0.00427)\end{array}$ & $\begin{array}{l}1.062 * * * \\
(0.00419)\end{array}$ & $\begin{array}{l}0.978 * * * \\
(0.00391)\end{array}$ & $\begin{array}{l}0.951 * * * \\
(0.00385)\end{array}$ & $\begin{array}{c}1.003 \\
(0.00402)\end{array}$ \\
\hline \multicolumn{13}{|c|}{ Canada: All Controls Included } \\
\hline Post 2000 Indicator & $\begin{array}{c}1.002 \\
(0.00916)\end{array}$ & $\begin{array}{c}1.003 \\
(0.00917)\end{array}$ & $\begin{array}{c}0.989 \\
(0.00895)\end{array}$ & $\begin{array}{c}0.985 \\
(0.00883)\end{array}$ & & $\begin{array}{c}0.979 * * \\
(0.00875)\end{array}$ & $\begin{array}{c}1.014 \\
(0.00903)\end{array}$ & $\begin{array}{l}1.030 * * * \\
(0.00917)\end{array}$ & $\begin{array}{l}1.050 * * * \\
(0.00933)\end{array}$ & $\begin{array}{l}1.049 * * * \\
(0.00946)\end{array}$ & $\begin{array}{l}1.059^{* * * *} \\
(0.00965)\end{array}$ & $\begin{array}{l}1.040^{* * * *} \\
(0.00958)\end{array}$ \\
\hline Constant & $\begin{array}{c}0.941 * * * \\
(0.0169)\end{array}$ & $\begin{array}{c}0.936 * * * \\
(0.0168)\end{array}$ & $\begin{array}{l}1.040 * * \\
(0.0182)\end{array}$ & $\begin{array}{c}1.003 \\
(0.0175)\end{array}$ & & $\begin{array}{l}0.966^{* *} \\
(0.0169)\end{array}$ & $\begin{array}{c}1.034^{*} \\
(0.0180)\end{array}$ & $\begin{array}{c}1.029 \\
(0.0180)\end{array}$ & $\begin{array}{c}1.077 * * * \\
(0.0186)\end{array}$ & $\begin{array}{c}1.007 \\
(0.0177)\end{array}$ & $\begin{array}{c}0.952^{* * * *} \\
(0.0170)\end{array}$ & $\begin{array}{c}0.971 \\
(0.0175)\end{array}$ \\
\hline \multicolumn{13}{|c|}{ US: All Controls Included } \\
\hline Post 2000 Indicator & $\begin{array}{l}0.905 * * * \\
(0.00688)\end{array}$ & $\begin{array}{l}0.964 * * * \\
(0.00742)\end{array}$ & $\begin{array}{c}0.983 * * \\
(0.00738)\end{array}$ & $\begin{array}{c}1.009 \\
(0.00762)\end{array}$ & & $\begin{array}{c}0.981 * * \\
(0.00736)\end{array}$ & $\begin{array}{c}1.035 * * * \\
(0.00768)\end{array}$ & $\begin{array}{c}1.005 \\
(0.00747)\end{array}$ & $\begin{array}{c}1.019 * * \\
(0.00763)\end{array}$ & $\begin{array}{c}1.003 \\
(0.00757)\end{array}$ & $\begin{array}{l}0.973 * * * \\
(0.00744)\end{array}$ & $\begin{array}{c}1.008 \\
(0.00767)\end{array}$ \\
\hline Constant & $\begin{array}{l}0.985 * * * \\
(0.00558)\end{array}$ & $\begin{array}{l}0.972 * * * \\
(0.00554)\end{array}$ & $\begin{array}{l}1.069 * * * \\
(0.00594)\end{array}$ & $\begin{array}{c}0.994 \\
(0.00558)\end{array}$ & & $\begin{array}{c}1.013 * * \\
(0.00566)\end{array}$ & $\begin{array}{l}1.129 * * * \\
(0.00621)\end{array}$ & $\begin{array}{l}1.111 * * * \\
(0.00612)\end{array}$ & $\begin{array}{l}1.077 * * * \\
(0.00596)\end{array}$ & $\begin{array}{c}0.993 \\
(0.00557)\end{array}$ & $\begin{array}{l}0.969 * * * \\
(0.00550)\end{array}$ & $\begin{array}{l}1.021^{* * * *} \\
(0.00576)\end{array}$ \\
\hline
\end{tabular}

Note: The constant represents the relative risk ratios for the pre-E.I. regime. To obtain the post-E.I. results, the constant and the Post-2000 Indicator must be multiplied together. The multiplied risk-ratios are what are presented in Figures 7a. 
Table A.5: Expected Month of Birth. Multinomial Logit Model. Relative Risk Ratios, Probability of birth in the month relative to May, By Marital Status and Age, Pre- and Post- January 1, 2001, Canada and the northern United States

\begin{tabular}{|c|c|c|c|c|c|c|c|c|c|c|c|c|}
\hline & Jan & Feb & Mar & Apr & May & Jun & Jul & Aug & Sep & Oct & Nov & Dec \\
\hline \multicolumn{13}{|c|}{ Canada: All Controls Included, Interaction with Married Dummy } \\
\hline \multirow[t]{2}{*}{ Post 2000 Indicator } & 1.001 & 0.998 & 0.990 & 0.984 & & $0.966^{\star * *}$ & 0.991 & 1.003 & $1.035^{\star \star *}$ & $1.022^{\star *}$ & $1.031^{\star * *}$ & 1.001 \\
\hline & $(0.0106)$ & $(0.0106)$ & $(0.0104)$ & $(0.0102)$ & & $(0.0100)$ & $(0.0102)$ & $(0.0103)$ & $(0.0106)$ & $(0.0107)$ & $(0.0109)$ & $(0.0107)$ \\
\hline \multirow[t]{2}{*}{ Married Indicator } & $0.959^{* \star *}$ & $0.952^{\star \star *}$ & $0.969^{\star * *}$ & $0.986^{\star \star *}$ & & $0.979^{\star \star *}$ & $0.949^{* \star *}$ & $0.934^{\star * *}$ & $0.927^{\star \star \star}$ & $0.934^{\star * *}$ & $0.919^{\star \star *}$ & $0.889^{* \star *}$ \\
\hline & $(0.00419)$ & $(0.00416)$ & $(0.00417)$ & $(0.00421)$ & & $(0.00419)$ & $(0.00405)$ & $(0.00399)$ & $(0.00395)$ & $(0.00404)$ & $(0.00402)$ & $(0.00389)$ \\
\hline \multirow[t]{2}{*}{ Married X Post 2000} & 1.002 & 1.008 & 0.998 & 1.001 & & $1.021^{\star \star}$ & $1.036^{\star \star \star}$ & $1.042^{\star \star \star}$ & $1.024^{\star \star \star}$ & $1.042^{\star \star \star}$ & $1.042^{\star \star \star}$ & $1.061^{\star * *}$ \\
\hline & $(0.00835)$ & $(0.00840)$ & $(0.00826)$ & $(0.00820)$ & & $(0.00834)$ & $(0.00843)$ & $(0.00845)$ & $(0.00826)$ & $(0.00854)$ & $(0.00862)$ & $(0.00886)$ \\
\hline \multirow[t]{2}{*}{ Constant } & $0.941^{* * *}$ & $0.938^{* * *}$ & $1.040^{* *}$ & 1.003 & & $0.970^{*}$ & $1.042^{* *}$ & $1.039^{* *}$ & $1.082^{\star * *}$ & 1.016 & $0.961^{* *}$ & 0.984 \\
\hline & $(0.0170)$ & $(0.0169)$ & $(0.0183)$ & $(0.0176)$ & & $(0.0171)$ & $(0.0182)$ & $(0.0182)$ & $(0.0188)$ & $(0.0180)$ & $(0.0173)$ & $(0.0178)$ \\
\hline \multicolumn{13}{|c|}{ US: All Controls Included, Interaction with Married Dummy } \\
\hline \multirow[t]{2}{*}{ Post 2000 Indicator } & $0.932^{* * *}$ & $0.986^{*}$ & 1.000 & $1.020^{* *}$ & & 0.996 & $1.033^{\star * *}$ & 0.999 & $1.020^{* *}$ & $1.026^{\star * *}$ & 1.009 & $1.032^{* * *}$ \\
\hline & $(0.00738)$ & $(0.00793)$ & $(0.00789)$ & $(0.00813)$ & & $(0.00787)$ & $(0.00805)$ & $(0.00780)$ & $(0.00802)$ & $(0.00813)$ & $(0.00807)$ & $(0.00821)$ \\
\hline \multirow[t]{2}{*}{ Married Indicator } & $0.916^{\star \star \star}$ & $0.928^{\star * \star}$ & $0.960^{\star \star \star}$ & $0.989^{\star \star \star}$ & & $0.969^{\star \star \star}$ & $0.930^{\star \star \star}$ & $0.924^{\star \star *}$ & $0.941^{\star \star \star}$ & $0.950^{\star \star \star}$ & $0.917^{\star \star \star}$ & $0.894^{\star \star \star}$ \\
\hline & $(0.00243)$ & $(0.00248)$ & $(0.00252)$ & $(0.00262)$ & & $(0.00254)$ & $(0.00240)$ & $(0.00239)$ & $(0.00245)$ & $(0.00250)$ & $(0.00244)$ & $(0.00236)$ \\
\hline \multirow[t]{2}{*}{ Married X Post 2000} & $0.965^{\star \star \star}$ & $0.979^{* \star *}$ & $0.983^{\star \star *}$ & 0.996 & & $0.984^{\star \star}$ & 1.001 & 1.003 & 0.991 & $0.970^{\star \star \star}$ & $0.949^{\star \star *}$ & $0.964^{\star * *}$ \\
\hline & $(0.00613)$ & $(0.00633)$ & $(0.00624)$ & $(0.00638)$ & & $(0.00625)$ & $(0.00627)$ & $(0.00630)$ & $(0.00626)$ & $(0.00618)$ & $(0.00610)$ & $(0.00616)$ \\
\hline \multirow[t]{2}{*}{ Constant } & $0.983^{\star \star *}$ & $0.970^{\star \star \star}$ & $1.071^{\star * *}$ & $0.992^{*}$ & & $1.008^{\star}$ & $1.126^{\star \star \star}$ & $1.107^{\star \star \star}$ & $1.072^{\star \star \star}$ & $0.988^{\star *}$ & $0.961^{\star \star \star}$ & $1.017^{\star \star \star}$ \\
\hline & $(0.00489)$ & $(0.00487)$ & $(0.00524)$ & $(0.00490)$ & & $(0.00496)$ & $(0.00545)$ & $(0.00537)$ & $(0.00522)$ & $(0.00488)$ & $(0.00480)$ & $(0.00504)$ \\
\hline \multicolumn{13}{|c|}{ Canada: All Controls Included, Interaction with Age Groups } \\
\hline \multirow[t]{2}{*}{ Post 2000 Indicator } & $0.969^{* * *}$ & $0.968^{\star * *}$ & $0.962^{\star \star \star}$ & $0.979^{*}$ & & $0.949^{* * *}$ & 0.983 & 0.988 & 1.017 & $1.023^{*}$ & $1.029^{\star *}$ & 1.016 \\
\hline & $(0.0114)$ & $(0.0114)$ & $(0.0112)$ & $(0.0113)$ & & $(0.0110)$ & $(0.0113)$ & $(0.0113)$ & $(0.0116)$ & $(0.0119)$ & $(0.0121)$ & $(0.0120)$ \\
\hline \multirow[t]{2}{*}{ Aged 25-34 } & $0.924^{\star * *}$ & $0.935^{\star \star *}$ & $0.960^{* * *}$ & $0.988^{* * *}$ & & $0.984^{\star * *}$ & $0.970^{\star \star *}$ & $0.965^{\star * *}$ & $0.966^{\star * *}$ & $0.976^{\star * *}$ & $0.980^{\star \star *}$ & $0.968^{\star * *}$ \\
\hline & $(0.00399)$ & $(0.00404)$ & $(0.00409)$ & $(0.00418)$ & & $(0.00417)$ & $(0.00410)$ & $(0.00409)$ & $(0.00409)$ & $(0.00419)$ & $(0.00427)$ & $(0.00422)$ \\
\hline \multirow[t]{2}{*}{ Aged 35+ } & $0.975^{\star \star \star}$ & $0.968^{\star \star \star}$ & $0.971^{\star \star \star}$ & 0.989 & & 0.998 & $1.015^{\star \star}$ & $1.034^{\star \star *}$ & $1.052^{\star \star \star}$ & $1.069^{\star \star \star}$ & $1.098^{\star \star \star}$ & $1.090^{\star \star \star}$ \\
\hline & $(0.00676)$ & $(0.00673)$ & $(0.00667)$ & $(0.00672)$ & & $(0.00679)$ & $(0.00688)$ & $(0.00700)$ & $(0.00710)$ & $(0.00730)$ & $(0.00757)$ & $(0.00755)$ \\
\hline \multirow{2}{*}{$\begin{array}{l}\text { Aged 25-34 X Post } \\
2000\end{array}$} & $1.048^{\star \star \star}$ & $1.049^{\star \star *}$ & $1.036^{\star \star \star}$ & 1.008 & & $1.046^{\star \star *}$ & $1.051^{\star \star \star}$ & $1.066^{\star \star *}$ & $1.061^{\star \star \star}$ & $1.045^{\star \star \star}$ & $1.048^{\star \star \star}$ & $1.039^{\star \star \star}$ \\
\hline & $(0.0102)$ & $(0.0102)$ & $(0.0100)$ & $(0.00965)$ & & $(0.0100)$ & $(0.0100)$ & $(0.0101)$ & $(0.0100)$ & $(0.0100)$ & $(0.0102)$ & $(0.0102)$ \\
\hline \multirow{2}{*}{$\begin{array}{l}\text { Aged } 35+\text { X Post } \\
2000\end{array}$} & $1.029^{\star *}$ & $1.044^{\star * *}$ & $1.034^{* *}$ & 1.010 & & 1.016 & 0.996 & 1.012 & $0.979^{*}$ & 0.992 & 1.001 & 0.995 \\
\hline & $(0.0136)$ & $(0.0138)$ & $(0.0136)$ & $(0.0131)$ & & $(0.0132)$ & $(0.0129)$ & $(0.0130)$ & $(0.0125)$ & $(0.0128)$ & $(0.0131)$ & $(0.0131)$ \\
\hline \multirow[t]{2}{*}{ Constant } & $0.946^{\star \star \star}$ & $0.942^{\star \star \star}$ & $1.045^{\star \star}$ & 1.004 & & $0.970^{*}$ & $1.039^{\star \star}$ & $1.036^{\star *}$ & $1.083^{\star \star \star}$ & 1.011 & $0.957^{\star \star}$ & 0.975 \\
\hline & $(0.0170)$ & $(0.0169)$ & $(0.0184)$ & $(0.0176)$ & & $(0.0171)$ & $(0.0181)$ & $(0.0181)$ & $(0.0188)$ & $(0.0178)$ & $(0.0172)$ & $(0.0176)$ \\
\hline
\end{tabular}


Note: The constant represents the relative risk ratios for the pre-E.I. regime. To obtain the pre-E.I. regime demographic results, the relative risk ratios from the constant and the demographic variable must be multiplied together. To obtain the post-E.I. results, the constant, the demographic variable, the Post-2000

Indicator, and the Post 2000 demographic variable must be multiplied together. The multiplied risk-ratios are what are presented in Figures $7 \mathrm{~b}$ and c. 